Poverty and Productivity in Female-Headed Households in Zimbabwe

Sara Horrell and Pramila Krishnan

July 2006

CWPE 0663 


\title{
Poverty and Productivity in Female-Headed Households in Zimbabwe
}

\author{
Sara Horrell and Pramila Krishnan \\ Faculty of Economics, University of Cambridge, Cambridge CB3 9DD
}

July 2006

\begin{abstract}
A household survey conducted in rural Zimbabwe in 2001 is used to compare the position of de facto and de jure female-headed households to those with a male head. These households are characterised by different forms of poverty that impinge on their ability to improve agricultural productivity. However, once inputs are accounted for, it is only for growing cotton that femaleheaded households' productivity is lower than that found for male-headed households. General poverty alleviation policies will benefit the female-headed household but specific interventions via extension services and access to marketing consortia are also indicated.
\end{abstract}

JEL classification: $\mathrm{O} 12$

\section{Keywords:}

Africa, Zimbabwe, gender, poverty, female-headed households, agriculture

\section{Acknowledgements}

This research forms part of the Department for International Development (UK) "Labour Markets, Gender and Pro-Poor Growth" project (R7615). We would like to thank DfID for funding the research, JIMAT Development Consultants, Harare, Zimbabwe for implementing the fieldwork, Hazel Johnson for co-organizing the project and for insightful comments on an earlier draft of this paper and anonymous referees for their helpful suggestions.

Accepted for publication by the Journal of Development Studies, July 2006 


\section{Poverty and productivity in female-headed households in Zimbabwe}

\section{Introduction}

The incidence of female headship is believed to have increased worldwide and, in both developed and developing countries, a high proportion of these households are found to suffer poverty (Chant 1997). Thus female-headed households have become an easily identifiable group on which to target poverty alleviation measures. However, the efficacy of such targeting has been widely questioned (Kennedy and Haddad 1994, Blackden and Bhanu 1999, Quisumbing et al 2001, Chant 2003). Female headship results from a variety of causes: widowhood, divorce and de facto headship, arising, for instance, from the illness of a spouse or his migration to an urban area to find work: and consequently does not map directly into poverty and deprivation. More work is needed to understand the relationship of forms of female headship to access to resources and the consequential effects on the ability to improve the household's position. Only when such links are documented can poverty alleviation measures be effectively and efficiently targeted.

Here we use data collected from a detailed survey of 300 households across three rural areas in Zimbabwe: Chivi in Masvingo province, Mutoko in Mashonaland East and Makoni in Manicaland: to explore the position of different types of female-headed household. ${ }^{1}$ The areas offer different agricultural potential and waged labour opportunities and Mutoko is a resettlement area. $^{2}$ Female headship in Zimbabwe is commonplace. Around two thirds of the population live on and work the rural communal lands (Chipika et al 1998, p.25). Possibly some $40 \%$ of the households located there are headed by women (Agritex 2002). This partly arises from labour migration. Typically men migrate to work in towns, mines or commercial farms while their wives farm the household's plots. But female headship is also becoming more frequent as the incidence of terminal diseases such as HIV/AIDS increases. Zimbabwe has an estimated 33\% of 15-49 year olds infected by the disease leaving grandmothers heading households for their grandchildren (ZNVAC 2002, p.27). At national level around one third of households are thought to be female headed (Chant 1997, p.90).

Two aspects of female-headship are investigated: whether there is a higher incidence of poverty in households headed by women and how female headship relates to the household's productivity in agriculture. Attention is paid to the form of female-headship. The survey recorded whether respondents were single, married, divorced or widowed. 17 women who stated they were heads of household were married and are thus classified as de facto female heads, 52 were

\footnotetext{
${ }^{1} 100$ households were surveyed in each area in 2001 . They were randomly selected but had to have an economically active head so the head was likely to be younger than average and unlikely to be chronically ill. The sample was stratified so that up to one quarter of the interviews would be with female heads of households. The remainder are male-headed households. A structured questionnaire was used and this investigated household production, work, divisions of labour and power and control within the household. A limited, more qualitative resurvey of 10 households in each of Chivi and Mutoko in 2003 investigated some issues in greater depth, for instance, changes in divisions of labour and access to networks.
}

\footnotetext{
${ }^{2}$ Chivi is in agro-ecological region V so has low rainfall and poor quality land. Agriculture is the main source of livelihood and here opportunities for waged labour are limited as the area lacks a vibrant economy. Mutoko is in regions III and IV. It has a strong emphasis on agricultural production and is a prime horticultural producing area. There are also local employment opportunities in mining and quarrying. Makoni is in agro-ecological regions IIb and III with good quality land and adequate rainfall. Increasinging agricultural incomes have led to non-farm employment creation in the area. Employment is also available in the adjacent large scale commercial farming area and the nearby urban area. Around 20 different crops are grown in each of Mutoko and Makoni, whereas only twelve crops are mentioned as being grown in Chivi. All areas grow maize, groundnuts and roundnuts.Cotton is grown in Chivi and Mutoko.
} 
widowed or divorced and so classified as de jure female heads. The remainder of the sample were households headed by males. ${ }^{3}$

Female headship is typically expected to increase the likelihood of the household being found amongst the poor. However, this hard to verify in general and World Bank data have indicated that while this may be true in Asia and Latin America it is less obviously the case in Africa (Chant 2003, p.49). Furthermore it may vary by type of female headship and be evident across dimensions other than income (Quisumbing et al 2001). Female-headed households are likely to have fewer income earners within the household than a comparable male-headed household, but de facto headship may be associated with high levels of remittances returned from work in urban areas which may be crucial to lifting the family out of poverty. Thus these households may be better off, at least in monetary terms, than the household where both partners remain engaged in rural and agricultural pursuits. But this rural-urban division of labour has required women to undertake all the agricultural tasks, thus curtailing the extent to which they can participate in the labour market (Gwaunza 1998). Migration may have constrained the ability of other family members to diversify their income-generating activities thus offsetting some of the income gain from remittances.

Much work has highlighted the many dimensions of poverty. ${ }^{4}$ Being income poor is the most obvious but being asset poor may be equally detrimental. Assets can cover the physical; from land and livestock to property and machinery; to human capital, such as education and the number of people available to work in the household, to social capital which enables people to engage in networks, to develop markets and mitigate risk. These assets may be more important than income in assuring the household's survival and determining its ability to improve its situation so need to be included in any assessment of poverty.

The household survey provides data that allow these aspects of the situation of femaleheaded and male-headed households to be compared. Information was collected on household structure, the types and amount of income the household was in receipt of, the consumption allowed by own agricultural production, asset ownership, indicators of social capital and participation in networks, and household members' activities and time use.

It has been asserted that women's productivity in agriculture is hampered both by their lack of assets and access to resources and by being female (Boserup 1970), although much evidence is only weakly supportive of this latter point (Quisumbing 1996). The survey data provide the opportunity to examine whether female-headship is associated with lower crop yields, and thus a reduced impact of work effort on poverty reduction. We develop a model which demonstrates the routes through which female headship might impact on agricultural productivity and profitability. We then use the survey information on inputs for and output of each crop grown to examine the factors determining yields per acre. Specific factors which might underlie any disadvantages associated with female-headship, such as a lack of males to act in markets for the household and lack of access to extension services, are considered further using the evidence collected in a resurvey of 20 of the original households.

\section{Household structure in Zimbabwe}

Shona society is deeply patriarchal. ${ }^{5}$ Traditionally bridewealth payments (lobola) have

\footnotetext{
${ }^{3}$ These household types were evenly distributed across the three regions studied. Initial analysis revealed few obvious differences in situation by area but regional variables are included in the regression analyses conducted in section 6.

${ }^{4}$ See, for example, World Bank 2000, Chant 2003, Ellis and Freeman 2004.

${ }^{5}$ All three of our survey areas are in Shona-speaking parts of Zimbabwe.
} 
been paid by men to women's families on 'engagement' and the movement of the woman to the husband's home occurred after the birth of the first child, when further payments fell due. The woman became subject to supervision by older female members of the man's family and enjoyed little power within that household. Concern was to maintain land and asset holdings within the male descendant group, thus all inheritance and most power travelled through the male line. ${ }^{6}$ However, women had some power in their own birth-family's arena. A woman's bridewealth was used to pay the lobola of her brother. This gave her a position of authority relative to his wife and his children. Thus, in traditional society, women were subject not only to their husband but to their husband's kin, but they did maintain some measure of influence in their brother's family. Polygamy was allowed but was not widespread. Men had to be able to support a first wife and family adequately before they could take on a second, this meant that, in rural areas at least, men with more than one wife tended to be older and to have acquired more material wealth and assets (Bourdillon 1976).

In more recent times some of the traditional arrangements have broken down. In particular, migration and the earning of cash by young men to make lobola payments has cut the tie to sister's bridewealth and removed her influence over his family (Bourdillon 1976).

Movement into Resettlement Areas has been accompanied by the reduced influence of husband's kin on women's lives and has give the household a nuclear family form (Jacobs 2000). However, male authority remains unchallenged. Communal law upholds male authority and state law tends to give precedence to communal law. Married women are effectively treated as minors under the law. They are not issued land in their own right in the Resettlement Areas and are unable to enter into contracts without their husband's joint involvement, thus they cannot own property independently. ${ }^{7}$ Land in communal areas is allocated by chiefs to the male head of the household. Even when male household heads are absent women may still be subject to their authority and, in rural villages, may also have to defer to their husband's male kin who will be concerned to protect the position of male heirs.

Male migration is an entrenched feature of the Shona household. Early twentieth century colonial policy aimed to create an available male labour force for the commercial farms and mines through the imposition of a hut tax that required cash for payment. However, the low wages paid reinforced the need for own-agricultural production for subsistence and no provision was made for cohabiting wives and families. Women remained in the rural areas to produce the necessary food and to provide a retreat for those too old or infirm to work (Bourdillon 1976, Davison 1997). This division of labour has continued. The substitution of cash for cows in lobola payments has made migration a typical option for many young men and many remain as migrants throughout their working years. Migration is a long-term strategy which may result in the return of remittances to the rural family. ${ }^{8}$ However, migrants often set up second households in urban areas leaving rural wives to largely fend for themselves until the migrant needs to return (Zimbabwe Human Development Report 2003). Furthermore, de facto female heads frequently lack control over resources and incomes. Absent husbands may appropriate money generated by wives for their own consumption. The dire consequences of such behaviour are starkly portrayed in the

\footnotetext{
${ }^{6}$ Exceptions here are certain women's power in contacting the spirit world and in religion and medicine.

${ }^{7}$ This has been reinforced by `fast track' resettlement since 2000 which allows widowed, divorced and single mothers to receive resettlement land in their own right but does not allow this for married women (Hellum and Derman 2004).

${ }^{8}$ The decision to have a member of the household as a migrant labourer will be part of the household's incomegeneration strategy along with crop production and other earning opportunities. In principle this would make de facto female-headship endogenous to the decisions. However, men typically migrate in youth to raise cash for bridewealth payments and may only intermittently cohabit with their wives in the rural areas. Thus migration and crop production decisions are likely to be intertemporally separate. We test for possible endogeneity in section 6 .
} 
suicides of 153 women in Gowke in 1997 caused by the contentious disposal of cotton money (ibid 2003, p.36).

Widows often fare no better. Customary law requires inheritance to pass through the male line thus bypassing the widow and daughters. Indeed wives are traditionally inherited by a kinsman of the husband, although the woman can refuse to be inherited. Under this arrangement she may be allowed to continue to farm the plots allocated to her by her husband (Bourdillon 1976). Women may not inherit if they were married under customary law. Land passes to the oldest son, possibly even the son of another wife, and the subsequent treatment of the widow is at his discretion. Some may manage the land on their son's behalf (Mate 2001). However, in Resettlement Areas, some widows have been allowed to inherit their husband's permit to the land and to continue farming. Whether this occurs is at the discretion of the resettlement officer (Jacobs 2000). Women married under the Marriage Act may inherit along with their children, but these form the rare minority. The Administration of Estates Amendment Act 1997 strengthens the position of widows and sons and daughters, but it is unclear how easy it will be to resolve disputes (Coldham 2000) and instances where widows have had to leave the rural home are still frequently observed (Ikdahl et al 2005).

The situation of the divorced woman is usually worse than that of the widow. On divorce the woman receives no share of the household's land or assets, she may have to leave her children with her husband and she may also have to hand over her possessions, such as clothes bought during the marriage and money saved from her own income-generating ventures (Pankhurst and Jacobs 1988). She is expected to return to her own kin and to be supported by them.

The degree of autonomy experienced in female-headed households is therefore uncertain and will vary according to individual circumstances. Indeed headship is a complex notion that can involve others outside the household and might differ according to the domain discussed (Vijfhuizen 2002). For instance, father, elder male relatives and aunts (vatete) were frequently cited as the person one would go to for help in solving major problems and were therefore described as head of household. However, women made most of the production, land and labour allocation and expenditure decisions in the two households studied in detail, leading to the conclusion that most households might be described as "female-managed" (Vijfhuizen 2002, p.100).

To overcome such complexities headship was self-defined in the survey analysed here. Respondents were asked their marital status and who was head of their household. Those women who replied that they were widowed or divorced and nominated themselves as the head of household constitute the group of 52 de jure female heads studied. Married women who said they were the head of household constitute our group of 17 de facto female heads. In most of these households husbands were absent; in the two where husbands were co-resident they might have been old or ill. Correlating this self-classification with information on power and control within the household confirms the greater autonomy of those designated as female heads. For each crop grown respondents were asked who decided to sell the crop, who made the sale and who kept the money from the sale. 33\% of women in male-headed households made the decision to sell maize compared with $89 \%$ of the female heads. For all crops grown, $48 \%$ of sale decisions were made by wives but only in $78 \%$ of cases where the wife made this decision did she keep the money. This was true for $88 \%$ and $100 \%$ respectively of women who headed their own households (Horrell et al, ch.7 table 7). Female heads were likely to have sole responsibility for many of the activities of the household and to have to take strategic decisions themselves. Wives rarely made these decisions or shouldered these responsibilities alone. Female headship confers more power and control in the household's affairs. 


\section{Poverty in female-headed households}

The structures of the female-headed households surveyed differ in predictable ways from that of the male-headed household (table 1). Households headed by widows have fewer people in their households. This is accounted for by the absence of a spouse and one less child, but is to some extent offset by a higher presence of other relatives. Widows are on average seven years older than male household heads. De facto female-headed households are smaller with younger heads than both the de jure female-headed and male-headed households, although they have only slightly fewer children than male-headed households. The education level of de facto female heads is similar to that of male heads of household but widows are considerably more likely to have had no education than the other two groups.

An initial indicator of the situation of these households is provided by considering their monetary income. Total money income includes income from remittances, earnings, crop and livestock sales, own business and savings. Female-headed households are considerably poorer than their male counterparts: households headed by widows have a total income just over half that of the male-headed household and de facto female-headed households have around three quarters of the income of the male-headed household. However, the difference is reduced once the smaller size of the female-headed household is taken into account. Total household income per person is higher in the de facto female-headed household than in the male-headed household. Despite earning significantly less from waged work, small businesses and livestock sales, the de facto female-headed household manages to achieve similar crop incomes to the male-headed household and is in receipt of considerably higher levels of remittances. De jure female-headed households, however, remain significantly poorer than their male-headed counterparts: per capita incomes are less than two-thirds of those found in male-headed households. The widowed households have lower levels of income from all sources except remittances and fare particularly badly on the income they receive from crop sales, waged work and business income.

Per capita measures take no account of the possible economies of scale available to the household. Using an adult equivalent measure that reflects both the lower consumption needs of children and the potential for economies of scale confirms the previous finding; widowed households are significantly poorer on a monetary income measure than their male-headed counterparts. ${ }^{9}$

Remittances have been identified as particularly important in assuaging female-headed households' vulnerability to poverty (Quisumbing et al 2001). De facto female-headed households are more likely to have a member of their household away than male-headed households but extra-household links are common to all types of household. Similar numbers of people are away from each household type and around three quarters of these return cash to the household regardless of the form of headship. However, de facto female heads receive high levels of cash from each person away, de jure female heads particularly low levels. Cash remittances are an important mainstay in meeting de facto female-headed households' income needs, they are a less important source for the de jure female-headed household.

Consumption is a more important variable than income in assessing poverty because it smoothes fluctuations over short periods of time. This is particularly the case for agricultural societies where large seasonal variations occur. Considering consumption takes on even more importance if a large amount of agricultural produce is consumed by the household and so

\footnotetext{
${ }^{9}$ The adult-equivalence scale adopted is

$\mathrm{AE}=$ (no. adults $+\alpha$ no. children) ${ }^{\theta}$

where $\alpha$ reflects the cost of a child relative to an adult and is set at 0.33 and $\theta$ reflects the extent of economies of scale and is set at 0.9 , following Deaton and Zaidi (2002, p.51). These values assume that children are not very costly in poor agricultural economies and that there is limited scope for economies of scale when food constitutes the main category of expenditure.
} 
remains non-monetised (Deaton and Zaidi 2002). The survey did not collect comprehensive consumption data, but it did record annual income data and information on the output of each crop and the proportion retained for own consumption. Giving this self-provisioned output the same value as any that is sold, or the average value of that sold locally if none is sold by the household, allows a better estimate of the income and consumption resources available to the household to be constructed. Including a value for self-provisioning heightens the differences observed in crop incomes between household types.

A comprehensive income figure further illustrates the impoverished position of the widowed household. Combining the household's gross monetary income with a value for selfprovisioned food and deducting seed, fertiliser and pesticide costs leaves a net income per capita measure that provides a reasonable proxy for consumption (table 2). The widowed household is significantly poorer than the male-headed household, the de facto female-headed household is more comparable. Income poverty is particularly prevalent amongst the de jure female-headed households. ${ }^{10}$ Comparing the distribution of income against an established poverty line emphasises this point (figure 1). ${ }^{11}$ While around three quarters of female-headed households and two thirds of male-headed households fall below the poverty line of Z\$8315, nearly two fifths of widow-headed households have incomes below Z $\$ 2500$ per annum per person whereas this is true for less than one quarter of male-headed households and one twentieth of de facto female-headed households. Widowed households are much more likely to be found amongst the very poor. The de facto female-headed household is less likely to be among either the very poor or the considerably better-off than the male-headed household.

Income provides only a limited insight into the situation of the household. A broader understanding requires consideration of its economic position and livelihood capabilities. An eclectic range of indicators is used to reflect both the entitlements and capabilities approach (Sen 1981, 1999, Dreze and Sen 1995) that describes the context in which decisions are made and the opportunities available and 'sustainable rural livelihoods' approach (Carney 1998) which focuses specifically on assets: human, physical, natural, social and financial. ${ }^{12}$ Indicators reflecting the number of economically active workers available to the household, the education level of the household, the land, property and financial assets owned and some indicators of social capital, such as links with others outside the household and participation in support programs and extension services, are combined to construct a household assets index. Each household is categorized in one of four spaces as income and asset rich or poor (table 2). ${ }^{13}$ Female-headed households are more likely to be asset poor than male-headed households: $76.9 \%$ of de jure and $82.3 \%$ of de facto female-headed households are asset poor compared with $66.3 \%$ of male-headed households: thus rendering them them more vulnerable to poverty.

Decomposition of the asset index identifies which assets female-headed households lack. With the exception of livestock, widowed households have only slightly lower levels of most

\footnotetext{
${ }^{10}$ Using an adult equivalent/ economies of scale measure as previously reveals the same tendency as the per capita measure.

${ }^{11}$ Poverty lines for two regions were developed in the Zimbabwe 1995 Poverty Assessment Survey. These have been
inflated to suggest real values in 1998 of $Z \$ 1151$ in Chivi and Z\$1169 in Mutasa for per capita food requirements and
$\mathrm{Z} \$ 1872$ and Z $\$ 1905$, respectively, for per capita total consumption. The total consumption figure for Mutasa is
adjusted for inflation using figures from the IMF International Financial Statistics, September 2002, p.148 for
consumer prices in Zimbabwe to give a per capita poverty line of Z\$8315 at the time the surveys were conducted.
}

${ }^{12}$ However, note that Bryceson (1999) points out that the SRL approach may have significant shortcomings in African societies where much income is generated from non-farm sources.

${ }^{13}$ To classify households as asset rich or poor the same proportion of households as found to be income poor were, when ranked, deemed to be asset poor. 
assets than male-headed households. Unfortunately there is no information on whether widows have fewer livestock because they only inherited a small number, have insufficient income to accumulate more or have had to make distress sales because of a lack of income. However, when asked under what circumstances they would sell livestock, widow-headed households were more likely than male-headed households to say they would never sell cattle (88\% versus $74 \%$ ) and were equally likely to sell goats and chickens when the household needed the money. De facto female-headed households have significantly lower levels of labour available to the household, smaller land holdings and less farm machinery ownership.

Consideration of the amount of land owned by region highlights the small plot sizes held by de facto female-headed households (table 3). As well as being less likely to own land at all, none own more than five acres whereas one fifth of the other types of household own more land than this. Despite per capita income levels that compare with those of male-headed households, de facto female-headed households suffer considerable asset poverty, particularly of assets important to agricultural production. Conversely, widow-headed households are no more likely than maleheaded households to own no land and they may farm quite sizeable plots. In Mutoko, the Resettlement Area, widows have the same average farm size as the male-headed household, confirming that resettlement officers are more likely to allow widows to inherit land than chiefs in the communal areas. But in Makoni and Chivi plot sizes are smaller than those observed for maleheaded households.

Assets have been identified as important in allowing the household to diversify and so mitigate risk and raise living standards (Ellis 1998). Consideration of indicators of the household's ability to diversify reveals that both type of female-headed household have fewer people engaging in remunerated activities and are more constrained in the number of income-generating activities they can engage in. Widows also keep fewer varieties of livestock (table 2). However after controlling for the level of income and ownership of assets through regression analysis it is apparent, firstly, how important assets are to all households in their ability to diversify whilst income levels play only a secondary role and, secondly, that de facto female-headed households are not constrained in their diversification by being female-headed, but widowed households are constrained in ability to enter the labour market and in keeping a wide variety of livestock.

A number of features emerge concerning the position of female-headed households. A distinction has been drawn between de jure and de facto female heads and it is clear that the situation of each is very different. De facto female heads tend to have a spouse and other family members working away who contribute some two-fifths of the household income. The household is quite young, its activities are concentrated on farming the household's own land and the woman bears most of the responsibility for farming this land. The household is not especially prone to income poverty and it may avoid the poorest reaches. But it does lack assets. ${ }^{14}$ Land, labour and farm machinery are in short supply and this constrains the ability of the household to diversify.

The de jure female head of household is usually a widow and older. She has more labour resources to draw on within the household, although remittances from children are also important. Her family has very low levels of income and they are likely to be amongst the poorest. But, with the exception of low levels of livestock ownership, they are not particularly disadvantaged in terms of asset ownership. However they are constrained in their ability to diversify. Widows again focus their labour activity on their own farms and they produce quite a high proportion of output

\footnotetext{
${ }^{14}$ It is possible that the intention of the migration strategy adopted by the household is to provide the income to accumulate assets. However, among the 20 households who participated in qualitative interviews only two were de facto female-headed and, of these, one received no remittances and the other spent the money on soap. Reinterviewed widowed households invariably spent any remittance money they received on food (4 cases). Only in two of the maleheaded households who received money from outside the household was the money used for other purposes, such as fees, paying workers and paying to grind meal
} 
for sale.

Gender inequality in access to productive, human and social capital assets has been implicated in low productivity, growth and output in Sub-Saharan Africa (Blackden and Bhanu 1999). The de facto female-headed households surveyed in Zimbabwe have fewer productive resources than other households. The de jure female-headed households also lack some productive, human capital and social capital assets. We use regression analysis of inputs into and outputs of agricultural activities to assess the extent to which lack of resources and being femaleheaded impinge on productivity.

\section{Agricultural productivity in female-headed households}

Widowed households own slightly less land than male-headed households. This results in a lower acreage of maize being grown but has little impact on other uses of the land. Similar acreages of groundnuts, roundnuts, cotton, rapoko and sweet potatoes are grown in both types of household (table 4). Widows are less likely to own each type of livestock than households with male heads and, where they do, they have fewer animals. This is particularly true for cattle. ${ }^{15}$ They are also less likely to own farm tools and equipment. The lack of these assets may constrain their crop production. Low levels of cattle and plough ownership mean reliance on other households for these inputs and widows may not be able to access them at the optimal time for planting. Indeed widows are more likely to have to hire draught power from outside the household than male-headed households.

De facto female-headed households are in a rather different situation. A number own no land and the others own less than half the acreage of the average male-headed household. Most of this land is devoted to the cultivation of roundnuts, groundnuts and maize. These households have less crop diversification and they concentrate on the traditional staples. Even so they have under three quarters of the maize acreage of male-headed households. De facto female-heads have similar levels of livestock ownership to the male-headed household but they are less likely to own most types of farm machinery. They are also less likely to be in receipt of any extension service, which could be either cause or consequence of the concentration on staple crops. ${ }^{16}$

The effects of these strategies and constraints can be observed in the average output and input usage for each of the four main crops (table 4). Maize production in households headed by widows shows relatively low yields per acre. Widows use fewer inputs than the male-headed household, which may explain the lower yields. Groundnuts (used for peanut butter and often fed to children) and roundnuts require few purchased inputs for their production and households headed by widows manage to achieve reasonable yields. One fifth of the de jure female-headed households grow cotton, but here their performance is relatively poor. Yields are less per acre in the widowed household than in the male-headed household despite a similar usage of most purchased inputs. De facto female-headed households demonstrate very low yields per acre for maize despite similar input usage to the male-headed household. ${ }^{17}$ These women again achieve

\footnotetext{
${ }^{15} 52 \%$ of widows keep cattle compared with $68 \%$ of male-headed households and $71 \%$ of de facto female-headed households.

${ }^{16}$ This was particularly true in Makoni where no de facto female-headed household was in receipt of an extension service. In general, in over two thirds of cases where extension advice was given it was on crop farming techniques, but the proportion was higher (81\%) for widow-headed households and lower for de facto female-headed households.

${ }^{17}$ Note that despite high non-agricultural incomes de facto female-headed households do not appear to be using this money to hire outside labour and so ensure more timely crop production and higher yields, which has been suggested as one route out of poverty (Ellis and Freeman 2004). However, it may be used to purchase livestock or cash inputs into agriculture.
} 
reasonable yields in groundnut and roundnut production. ${ }^{18}$

Some features emerge from this preliminary consideration of agricultural techniques. Female-headed households appear to be as efficient as male-headed households in growing and selling traditional female crops such as roundnuts and groundnuts where techniques have remained largely unaltered and production is dependent on labour inputs rather than purchased inputs. In areas such as maize and cotton production women-headed households appear to be at a disadvantage. The low yields for maize achieved in widow-headed households may be due to lower levels of input usage and lack of available draught power. Even in the de facto femaleheaded household inputs may have a role to play. It has been observed that better-off households achieve good maize yields as they can afford to purchase certified seed whereas the poor are more likely to plant seed retained from the previous year's harvest. Quality of seed will affect yields even where similar quantities are used. However, input usage is not the only difference. Output prices achieved indicate that de facto female-headed households, particularly, are achieving lower prices for their output (table 4). Women may also be facing higher input costs. These problems may arise because women are disadvantaged in selling arrangements and in procuring inputs. For instance, a lack of resources may constrain the household to buying small packets of seed and exclude them from consortia for purchasing inputs and hiring labour. Lack of resources may also require the female-headed household to sell crops at a disadvantageous time and so realise a lower output price. In cotton growing, widows used similar inputs but achieved lower yields and received a worse farm gate price than male-headed households. Cotton production is labour and input intensive, requiring pest and disease control and effective management. These factors determine quality and hence price. Cotton growing has traditionally been the preserve of the better-off household that has the requisite inputs, but government programs to support other producers have enabled poorer households to grow cotton. However, without the necessary experience and access to inputs low grade cotton will result. Thus input usage, the resource level of the household and, possibly, gender-based differences in access and ability all emerge as possible determinants of the lower productivity and agricultural incomes observed in femaleheaded households. In the next section we outline a model of market failure that captures some of these effects in a stylised fashion to illustrate the possible effects on productivity in female-headed households and specify an empirical test.

\section{A Theoretical Framework}

We begin with a variant of an agricultural household model with complete markets and assume that there is one market failure in that land markets are assumed to be non-existent, which is consistent with the situation in Zimbabwe. (Note that if this were the only market failure, the household decides its allocation in production independently of consumption as in a world with complete markets, for the household will choose labour inputs to maximise profits given the endowment of land as demonstrated below (Bardhan and Udry 1999)). The household is assumed to maximise a (well-behaved) utility function defined over the consumption of food (obtained from own production and purchased elsewhere), manufactured goods (which are assumed to be purchased but not produced at home) and leisure.

$$
\operatorname{Max} U\left(C_{f}, C_{m}, L\right)
$$

subject to:

$$
p_{f} C_{f}+p_{m} C_{m}+p_{w} L \leq \Pi+p_{w} T
$$

\footnotetext{
${ }^{18}$ Only one de facto female-headed household grew cotton.
} 


$$
\begin{aligned}
& Q_{f}=F\left(N_{f}+H_{f}, A_{f}\right) \\
& \Pi=p_{f} Q_{f}-p_{w} N_{f}-p_{w} H_{f} \\
& A_{f} \leq A \\
& L+N_{f}+N_{h}=T \\
& C_{i}, L, N_{f}, A_{f}, H_{f}, N_{h} \geq 0
\end{aligned}
$$

$C_{i}$ denotes consumption of one of two goods: a food crop $f$, a manufactured good $m$ and $L$ denotes leisure. $Q_{f}$ denotes the production function for the food crop, defined over two inputs: land and labour (both own and hired).

$p_{i}$ denotes prices of each good, $i=f, m ; p_{w}=$ market wage; $N_{f}$ denotes own labour input; $N_{h}$ denotes labour hired out; $H_{f}$ denotes hired labour input; $A_{f}$ denotes land area under cultivation and is the only capital input. (Other inputs such as seed can be readily introduced). $A$ and $T$ denote the household's endowment of land and time. $\Pi$ denotes the profits from food production. Note that the problem is recursive and the optimal value of utility is increasing in $\Pi$.

Optimal labour supply and output functions are then given by the solution to the following recursive program:

$$
\operatorname{Max} U\left(C_{f}, C_{m}, L\right)
$$

subject to:

$$
p_{f} C_{f}+p_{m} C_{m}+p_{w} L \leq \Pi^{*}(w ; A)+p_{w} T(9)
$$

where

$$
\Pi^{*}=\operatorname{Max} p_{f} Q_{f}-p_{w} N_{f}-p_{w} H_{f}
$$

Optimal production plans entail:

$$
p_{f} \frac{\partial \mathrm{F}_{f}(A)}{\partial \mathrm{N}_{f}}=p_{w} ; p_{f} \frac{\partial \mathrm{F}_{f}(A)}{\partial H_{f}}=p_{w}
$$

This in turn suggests that productivity of labour should be a function only of prices and land endowment. To the extent that there is heterogeneity in unobserved land quality, this will play a role as well. Effectively, despite the failure of markets in land, the household chooses labour inputs to maximise profits, conditional on its endowment of land. This is independent of its preferences over leisure.

However, in the Zimbabwean context, women face barriers in access to both labour and product markets. We wish to indicate the differences in allocation that might arise if femaleheaded households face different prices in these markets relative to male-headed households. We 
turn now to the case where female-headed households face restrictions on hiring labour in or out, in addition to the failure of land markets (for all households). The set-up is as laid out above except that $H_{f}=N_{h}=0$ for women and the constraint in equation (6) is modified as:

$$
L+N_{f}=T
$$

The optimisation problem can be cast as a Lagrangean optimisation problem, as below, where $\lambda$ represents the shadow price of the income constraint:

$$
\operatorname{Max} U\left(C_{f}, C_{m}, T-N_{f}\right)+\lambda\left[p_{f} \mathrm{~F}\left(N_{f}, A\right)-p_{f} C_{f}-p_{m} C_{m}\right]
$$

Now at the optimum, factor productivities will be a function of prices, preferences and the household's endowment of both labour and land.

$$
\frac{U^{\prime}\left(N_{f}\right)}{U^{\prime}\left(C_{f}\right)}=\frac{\partial \mathrm{F}_{f}(A)}{\partial N_{f}}
$$

This offers us the basis for an empirical test: the productivity of female-headed households is likely to depend on household structure and endowments. Furthermore, market failures in women's access to labour markets will in general result in profits for women below profitmaximizing levels, since the latter may not be obtained. The more serious the market failures, the lower the returns for women. This in turn forms the basis of an empirical test: average returns will be a function of household structure and the returns for female-headed households ought to be lower if the market failures bite harder for them. It also suggests that if household structures are endogenous in that female-headed households occur primarily because male heads of households have migrated elsewhere in search of work (so that part of the household has hired itself out), this in turn must be corrected for appropriately. Combining both kinds of households in one empirical model would lead to misleading results. However, if female-headed households are unsupported by remittances and face particular barriers in access to markets that raise relative prices to them in particular, average returns should again be lower for such households. We abstract from this possible endogeneity by also considering agricultural productivity only for those households without remittances.

The model can readily be extended to cover failures in other input markets, for instance, seed. We can introduce another input into the production function. If female-headed households face higher prices for seed (due to the inability to purchase in bulk, for instance), the productivity of seed in such households will be higher than that of male-headed households, since they will use less seed relative to the optimum. Again, if this were the only market failure, they would be able to maximise profits by reallocating labour and land. In the face of an additional market failure in land or labour, factor productivities will no longer be a function of prices but also of endowments and preferences and will deviate from the profit-maximising level. Productivity and profits are thus lower due to these market failures for those most seriously affected. This prediction is the basis of our empirical specifications in the next section.

\section{The Empirical Model and Results}

Our interest lies in testing whether headship of the household affects agricultural productivity. We begin by assuming that the production function of the farm manager in these settings is given by a Cobb-Douglas production function:

$$
Y \text {; } A L^{\Theta} K^{\mathcal{Q}}
$$

where $\mathrm{Y}$ is output, $\mathrm{L}$ is labour input and $\mathrm{K}$ a range of capital inputs. The empirical specification 
concentrates not on output but on yield (to capture average returns): output per unit of input, where the dependent variable is yield per acre and the input variables are expressed in terms of inputs per acre. Taking the logarithmic version of this production function and denoting the per acre transformation in lower case and further augmenting the equation to include the headship of the household (F) and other controls (a vector, Z that includes other household characteristics) we obtain:

$\ln y=\alpha_{0}+\alpha_{1} \ln l+\alpha_{2} \ln k+\alpha_{3} F+\beta Z+\varepsilon$

Note that in a world devoid of market failures, the vector of controls, Z, and headship, F, should not matter, abstracting from unobserved heterogeneity. However, market failures will mean that household characteristics and endowments, (apart from capturing heterogeneity in say, unobserved ability), will matter more generally since returns will now depend both on own characteristics and endowments for all households. The inclusion of $\mathrm{F}$ allows us to test whether there is an extra impact on efficiency if the household head is female, even after controlling for other household characteristics and endowments.

This is our basic estimating equation but it requires adjustment for two factors. First, for crops other than maize, only some households grow the crop. To estimate the above equation by OLS ignores the possibility of sample selection bias: certain factors may predispose the household to grow, say, cotton. To account for this potential bias a maximum likelihood Heckman selection model is used to account for selection into the group that grows the crop. The identifying variable in the selection equation (apart from the exogenous variables in the yield equation) is whether the house is legally registered in the name of someone in the household. Other variables included are the number of people in the household, the total acreage of land available, the education level of the household and gross household income per capita net of crop sales (non-agricultural income). These variables reflect the need for subsistence maize production, the ability of the household to diversify its crop production and proxy the level of risk this might entail. These variables cannot be excluded from having an impact on crop yields, however, home ownership is deemed to be exogenous to the productivity equation. ${ }^{19}$ Second, the survey sample is collected from three regions and this clustering may bias the standard errors calculated. Robust standard errors are calculated to account for this. ${ }^{20}$

In each case the dependent variable was the yield per acre of the specified crop. Labour inputs included both labour available to the household and hired outside labour for each crop. Capital inputs included the amounts of fertiliser, manure and seed used per acre and the acreage devoted to the crop. The asset base of the household was reflected in the number of cattle owned and the ownership of farm machinery (which also capture inputs from these sources) and the educational level of the household. Non-agricultural income per capita was included to reflect the possibility that households with outside income might be better able to purchase quality seeds or to hire labour and draught power. Conditioning variables were region, reflecting the agro-

\footnotetext{
${ }^{19}$ Regression analysis revealed that choices about whether to grow the crop were influenced by some of the additional posited variables. Groundnut and roundnut production were less likely if the household had high education or nonagricultural income respectively. These are low value crops that are largely important as nutritious supplements to diet and have limited commercial potential, although groundnuts are increasingly processed and sold as peanut butter. Households with education and/or income may opt to use labour and land resources in other, more profitable uses. Cotton production was more likely where the household was large and had more land. However, higher levels of nonagricultural income reduced the likelihood of this crop being grown, possibly because it indicated that the household had chosen alternative ways to diversify. Home ownership also reduced the likellihood of growing cotton.
}

\footnotetext{
${ }^{20}$ See Quisimbing (1996) for a detailed account of the techniques appropriate for identifying gender differences in agricultural productivity.
} 
ecological conditions, and the type of household head. The results of these regressions are reported in table $5 .^{21}$

However, two potential endogeneity issues remain. The Heckman selection procedure relies on identifying a variable exogenous to the yield equation. Legal ownership of the house is believed to be such a variable but given the difficulty of obtaining convincing exclusion restrictions, we also offer tobit estimates of the parameters, abstracting from the difficulty of endogenising crop choice. ${ }^{22}$ Yet another potential endogeneity problem is that of headship. As demonstrated in section 5, female-headedness, particularly de facto, may itself be endogenous to yields. A household may decide to supply a migrant labourer because of low productivity in agricultural activities, maybe because of poor land quality. Thus these households are likely to have lower yields. We examine the implications of the possible endogeneity of household structure by repeating the regression analysis only for those households who are not in receipt of remittances and so confirm the robustness of the original results.

For all crops, inputs per acre were important in improving yields per acre (table 5). The labour available to the household, manure, fertiliser and seed used per acre largely determined output. Only for maize production were the ownership of farm machinery and the amount of outside labour used significant in determining yields. The data in table 4 indicated that women may be disadvantaged in cultivating maize but the regression results show that the production techniques used explain most differences. However, gender was important in the cultivation of cotton. Even after accounting for inputs and assets, women-headed households achieved lower cotton yields than male-headed ones. ${ }^{23}$

Tobit regressions confirm these results. Estimating the decision to grow the crop together with yields reiterates the importance of manure, fertiliser and seed inputs in achieving high yields and again finds significantly lower cotton yields for female-headed households. Being a female head did not affect groundnut or roundnut yields. ${ }^{24}$ Repeating the Heckman selection model estimation only for those households who did not receive remittances also replicated the earlier results. Although a few variables lost their previous significance, ${ }^{25}$ female-headed households still achieved significantly lower cotton yields but no difference was revealed for groundnut and roundnut yields. ${ }^{26}$ OLS estimation of maize yields for those households without remittances found

\footnotetext{
${ }^{21}$ Access to extension services, the price of seeds per kilogram and the number of draught power hired for each crop were also included but never proved to be significant so were dropped from most of the final regressions. The insignificance of extension services was surprising but thought to result from the small proportion of households, around one quarter, in receipt of extension services related to agricultural production and the difficulties of identifying to which, if any, of the crops analysed the advice related.

\begin{abstract}
${ }^{22}$ In a small number of cases crop failures appear to have occurred. That is, inputs were used but no output was recorded. This was true for four households who grew maize, ten households who grew roundnuts, nineteen out of the 205 households who had grown groundnuts, but none of the households who grew cotton. In most cases the crop failures occurred in Chivi. The determinants of the zero yield were thought to be very different to those determining a positive yield (one respondent attributed the failure to water logging) so these cases were omitted from the main regression equations but they are included in the tobit regressions and the results compared.
\end{abstract}

${ }^{23}$ The significance of being female headed was unaltered by the inclusion of separate de facto and de jure dummy variables.

${ }^{24}$ The tobit regressions no longer found labour available to the household to be significant in either groundnut or cotton production and fewer variables were significant in the groundnut equation than found when using the Heckman estimation.

${ }^{25}$ The amount of labour available to the household and whether the house was legally registered were no longer significant in the cotton equation and manure inputs lost their significance in the groundnut and roundnut equations.

${ }^{26}$ Tobit regressions performed on this subsample of households again confirmed the significance of the female-headed
} 
a positive effect of being female-headed. ${ }^{27}$ This may indicate that these households are the most constrained and so have to put all their land to maize cultivation, whereas their unconstrained crop allocation would involve diversification and higher total profits. In fact only five of the femaleheaded and seventeen of the male-headed households grow only maize. ${ }^{28}$ The median number of crops grown for both types of household is four. Re-estimating the maize equation for all households but including an interaction term for being female-headed without remittances with the number of crops grown other than maize does not result in either significant interaction terms or a significant female-headed dummy variable.

This analysis of agricultural productivity indicates that women-headed households are disadvantaged in producing cotton, even after accounting for differences in input usage. ${ }^{29}$ The source of this disadvantage is unclear. It may result from insufficient experience and support, poor quality inputs or the inability to procure inputs in a timely fashion.

Certainly a lack of support has been identified elsewhere. AGRITEX ${ }^{30}$ recently assessed whether gender barriers inhibited women from benefiting from agricultural development programs (Agritex 2002). The study found that women had limited access to many factors of production, lacked resources and found it harder to access credit, training and extension services. Access to land was an important factor in these other shortages, particularly credit, but women also lacked draught power and suffered marketing difficulties. The report identified the problems women faced in accessing extension services. Men were wary of allowing women to attend training sessions unless they were provided in group settings, other time commitments often precluded women from attending, the technologies being advanced required physical strength and some new technology increased the need for tasks traditionally done by women, such as weeding. Additionally de facto female heads of household might be keen to conduct on-farm trials but may have to get permission from their husbands that, where granted, sometimes caused delays in meeting planting dates. The report concluded that extension services did not meet the needs of female farmers.

Analysis of input usage allows further consideration of the constraints that may be faced by female-headed households. Differential yields could imply an inefficient allocation of factor inputs across household types, hence, absent or poorly functioning markets. Such misallocation can be detected by significant gender variables in input intensity analyses (Udry 1996). The inputs of household labour time and total labour time used for the production of the crop, ${ }^{31}$ manure, fertilizer and seed per acre is considered for both maize production and across up to five different

household dummy variable for cotton production.

\footnotetext{
${ }^{27}$ The amount of paid labour used lost its significance but seed inputs became positive and significant.

${ }^{28} 13 \%$ and $10 \%$ of those households without remittances respectively.

${ }^{29}$ In Burkina Faso, Udry (1996) finds yields to be lower on plots farmed by women for all crops indicating an inefficient allocation of resources within the household. Here resource allocation appears less affected by household type, although inefficiencies are clearly evident in cotton production.
}

\footnotetext{
${ }^{30}$ AGRITEX is an agency for providing training and advisory services for agricultural development and efficiency in Zimbabwe.

${ }^{31}$ In the survey respondents were asked how long each member of the household spent in their main activity each day, they were also asked what, if any, was each person's secondary activity. Summing the number of hours at main activity where this was own-farm agricultural work and allocating two hours per day where it was mentioned as a second activity allows the household's labour contribution to be calculated. In addition there was information on labour time supplied by others considered to be part of the household and supplied by outsiders as well as the number of hired labourers used in the cultivation of each crop. This allows computation of the total labour time supplied to own-farm work.
} 
crops per household for which we have detailed input usage from the survey. ${ }^{32}$ Controlling factors include the labour available to the household, the availability of draught power, manure and machinery, all of which may affect the techniques adopted and the inputs used. The amount of non-crop income reflects the ability to buy in bulk or to hire in factors of production and the acreage of land allows for economies of scale in input usage. Education level, age of head of household and receipt of an extension service reflect knowledge of and willingness to use best practice techniques and variables are included to control for land quality. Female-headship dummy variables identify constraints in input usage faced by women. ${ }^{33}$

The results for inputs into maize production reveal little misallocation of resources by household type (table 6). Although de facto female heads use significantly less household labour in the production of maize this effect disappears when total labour used is the dependent variable. Household work hours per capita are lower in the de facto female-headed household than in the male-headed household and the number and ages of children in the household lies behind this difference. However, de facto female-headed households appear to have sufficient access to labour from non-resident household members, others in the village and, possibly, hired labour to correct this imbalance.

Analysis of the inputs into all crops shows the same tendency for de facto female-headed households to use less household labour but, again, for outside labour to make up for this deficiency. Additionally the interaction term between female-headed and growing cotton is also significant and negative for manure usage. Fewer women use manure in growing cotton than do men (table 4), which may reflect the limited ownership of livestock by widows.

Overall, the analysis of input usage suggests limited inefficiencies in women's ability to access the requisite quantity of inputs for crop production. Market failures do not bite significantly harder for women. However, it remains possible that women heads of household are constrained to use poorer quality inputs, particularly seed, and that they may also pay disproportionately high prices.

We can investigate the choice to purchase and the price paid per kilogramme for fertiliser and seed for maize and cotton production. Higher prices paid by women would imply their inability to buy in large quantities or their exclusion from purchasing consortia, lower prices would imply more use of retained, poor quality inputs. ${ }^{34}$ Regression analysis of price paid uses variables that control for land quality, ability to purchase inputs (income), effectiveness in dealing in markets (education), information (extension service), a proxy for membership of networks (a constructed social capital variable) and economies of scale (land ownership). These regressions do not identify female headship through either the quality or cost routes as a source of disadvantage in these market transactions (table 7).

Other, qualitative, evidence does suggest that women are inhibited from participating in purchasing consortia. Twenty households from the original survey were revisited to obtain

\footnotetext{
${ }^{32}$ Maize and all crops together are considered because investigating inputs for the other crops would require consideration of the crop choice and allocation across crops, which is beyond the potential of the current data.

${ }^{33}$ Data on weight of manure and fertiliser used was collected. These cannot be meaningfully aggregated so have to be analysed separately. Tobit regressions are used to reflect the choice made by some households not to use one of these inputs.

${ }^{34}$ Not all households that grew the crop purchased fertiliser and seed inputs; some used retained seed, others did not purchase fertiliser and may have used manure instead. Widows were slightly less likely than male heads of household to purchase seed and fertiliser for maize production and seed for cotton production (where one third appear to be using retained seed compared with one sixth of men), but they were more likely to purchase fertiliser for cotton production. De facto female heads were more likely than male household heads to purchase both seed and fertiliser for maize production, thus implying that poor quality inputs are unlikely to be the source of poor yields. Tobit analysis is used to incorporate the zero observations.
} 
information on issues such as the role of buying and selling consortia in crop production. Respondents were asked, both as individuals and through cluster interviews conducted in the villages, how they purchased their inputs, specifically seeds, fertilizer and pesticides. Most people bought individually from shops but there was an indication that female-headed and poor households were more likely to have to use credit from the Grain Marketing Board. Only one (male-headed, income-rich) household reported buying as part of a group from the ZFU. People acknowledged that group buying was preferable because it was cheaper and discounts were available, but poor households were excluded from these consortia because of the small quantities they required and the hazard associated with delays. Often people did not have the money available until late in the cropping season which delayed group buying. The consequent delay in using the seed and fertilizer purchased reduced crop yields. "We buy individually because some quickly get money to buy inputs and others do not" (cluster interview, Gurure, Mutoko). Incomepoor households are at a disadvantage in buying transactions, they are unable to benefit from any discounts offered and are more likely to have to purchase on less favourable credit terms. De jure female-headed households, particularly, are likely to be income poor.

Earlier it was noted that women farmers appear to achieve lower prices for their output (table 4). Regression analysis of the prices achieved for maize, groundnut and cotton sales can help identify whether there is a specific disadvantage faced by women in product markets. Again this could arise from poor quality of the crop or because women lack access to selling networks. De facto female heads selling maize achieve significantly lower prices for their crop when other influences are controlled for and widows are at a large disadvantage in cotton sales (table 7). The lower usage of retained seed and greater likelihood of purchase of fertiliser by de facto femaleheaded households makes poor quality inputs and hence low yield, poor quality output improbable. The larger amount of non-crop income flowing into these households also suggests less need for inopportune sales. Instead selling networks are pointed up. Qualitative evidence from the resurvey supports this interpretation. People were asked how they sold their crops: directly to a trader, to neighbours, through groups formed with other farmers or to the Grain Marketing Board? Female-headed households were more likely to sell through GMB, regardless of whether they were rich or poor; $70 \%$ sold this way, compared with $33 \%$ of male-headed households. The income-poor, male-headed household was likely to sell to traders and the income-rich, male-headed household to sell individually. Selling to GMB had the advantages that sellers got a lump sum amount and instant payment, but there were also disadvantages: "the people at GMB will tell you it still has high moisture content causing lots of inconveniences to my payment through delays.” The cost of transport featured as important in the most preferred selling method: "I would prefer selling to individuals because you have no transport costs, and you get your cash there and then", a view reflected in "now we sell to individuals at a higher price. They actually come and buy.” Women, then, were selling through the standard outlet but this was not necessarily the one that offered the best return. The resurvey indicates that female-headed households, and the poor more generally, are constrained in their selling options and so find themselves at a disadvantage when it comes to realizing the profitability of their crops. ${ }^{35}$

In summary, for maize we find no difference in yields achieved or input usage by femaleheaded households. Allocative inefficiencies appear to be absent. However, de facto female heads of household do receive low prices for their output and a lack of access to selling consortia may be the source of this disadvantage. In cotton production de jure female-headed households achieve low yields. Manure inputs are lower and there is a hint that more fertilizer and less purchased seed

\footnotetext{
${ }^{35}$ The qualitative survey asked respondents how important a variety of things were to their household and whether their need for each was met. Of the inputs required for agriculture, better quality land, improved inputs and better tools were all rated as very important by large numbers of respondents, but more people cited `markets for your produce' as very important than any of the other items. In many cases the household felt these needs were not met.
} 
are used. However extension advice and experience are also implicated. Only one third of households in the survey were in receipt of an extension service and for some this was not croprelated advice so, unfortunately, it is not possible to explore this aspect further within this data set. These women achieve a low price for their output. This may reflect poor techniques being employed and, hence, a low quality crop, but lack of access to selling networks may also be a factor. A picture emerges where much might be done to improve profitability of crop production for female-headed and poor households through both higher yields and better realised prices. The terms on which households engage in markets emerge as important. Better access to group buying and provision of transport to sell produce would help the position of these households. But the disadvantaged position of women in cotton production points to the importance of access to modern techniques and knowledge of good management practices. Extension service provision is crucial. ${ }^{36}$ Achieving higher yields is also dependent on having more and better quality inputs.

\section{Conclusion}

Female-headed households in rural Zimbabwe suffer the same problems as the poor more generally and poverty alleviation policies should benefit the female-headed household as much as the male-headed one. However, some specific disadvantages associated with female-headship have been identified. De facto female-headed households are not unusually income poor but they do lack assets, particularly those assets needed for agricultural production. This constrains their ability to diversify both in terms of the types of crops grown and in taking advantage of any local labour market options. But they don't disproportionately lack income or education. Thus with more resources and support from extension services they may be well placed to improve their position through, for instance, crop diversification. Even without additional resources, greater profitability could be achieved from their existing agricultural output through access to better selling networks and buying consortia for inputs. De jure female-headed households differ in that they lack income and are more likely to be among the very poor. However, they have similar physical asset bases to male-headed households, with the exception of livestock, and achieve similar levels of crop diversification. Lack of inputs constrains their productivity but improvements in yields given existing resources could be achieved in cotton production and better extension service availability might be key to this. The resultant higher incomes accruing to both types of female-headed household from such changes might be sufficient to allow asset accumulation and to enable them to start the climb out of poverty.

\footnotetext{
${ }^{36}$ Improving output markets and provision of extension services has been highlighted elsewhere as crucial to improving the situation of the poor in African countries (Ellis and Freeman 2004).
} 


\begin{tabular}{|c|c|c|c|}
\hline & \multicolumn{3}{|c|}{ Male-headed Female-headed households } \\
\hline & Households & Widow & De facto \\
\hline Sample size & 231 & 52 & 17 \\
\hline Number in household & 5.55 & 4.31 & 3.88 \\
\hline \multicolumn{4}{|l|}{ Average number of: } \\
\hline Spouses & 0.86 & 0.00 & 0.12 \\
\hline Children & 2.82 & 1.85 & 2.24 \\
\hline other relatives & 0.77 & 1.40 & 0.50 \\
\hline unrelated & 0.03 & 0.06 & 0.00 \\
\hline Age of respondent (mean) & 44.0 & 51.4 & 38.3 \\
\hline \multicolumn{4}{|c|}{ Highest level of education of male / female heads (\% in group): } \\
\hline None & 8 & 31 & - \\
\hline Primary & 59 & 60 & 65 \\
\hline Secondary & 29 & 10 & 35 \\
\hline Higher, formal training or vocational & 3 & - & - \\
\hline \multicolumn{4}{|l|}{ Household income } \\
\hline Total income (Z\$) & 32601 & 17319* & 24928 \\
\hline \multicolumn{4}{|l|}{ \% total income from: } \\
\hline Money from outside household & 12 & 26 & 43 \\
\hline Income from crop sales & 40 & $40 *$ & 47 \\
\hline Livestock, produce, equip. rental & 5 & 6 & $0 *$ \\
\hline Waged income & 7 & $2^{*}$ & $2 *$ \\
\hline Other income & 36 & $26 *$ & $8^{*}$ \\
\hline Total household income per person (Z\$) & 6784 & $4395 *$ & 7139 \\
\hline Adult equivalent household income (Z\$) & 11536 & $7103^{*}$ & 13687 \\
\hline \multicolumn{4}{|l|}{ Gross crop income, including } \\
\hline Value of self-provisioning ( $Z \$)$ & 25357 & 11490 & 13797 \\
\hline $\begin{array}{l}\% \text { households with someone away from home, } \\
\text { considered to be part of household }\end{array}$ & $35 \%$ & $46 \%$ & $71 \%$ \\
\hline Average number of people away & 1.9 & 1.9 & 1.6 \\
\hline \multicolumn{4}{|l|}{ Relationship of those away (\% of total away) } \\
\hline spouse & 11 & - & 56 \\
\hline child & 66 & 93 & 39 \\
\hline other relative & 23 & 7 & 6 \\
\hline \multicolumn{4}{|c|}{ Contributions returned to the household (\% of all away) } \\
\hline none & 14 & 9 & 22 \\
\hline cash & 71 & 76 & 72 \\
\hline days of labouring & 15 & 16 & 6 \\
\hline \multicolumn{4}{|l|}{ Mean amount of cash received per person away } \\
\hline For those receiving cash (Z\$) & 8981 & 3441 & 13862 \\
\hline
\end{tabular}

* t-test for equality of means of income variables (performed on absolute income levels), equal variances not assumed, significantly different from levels for male-headed households at $5 \%$ level or higher 
Table 2. Poverty profile and average component scores by gender of head of household

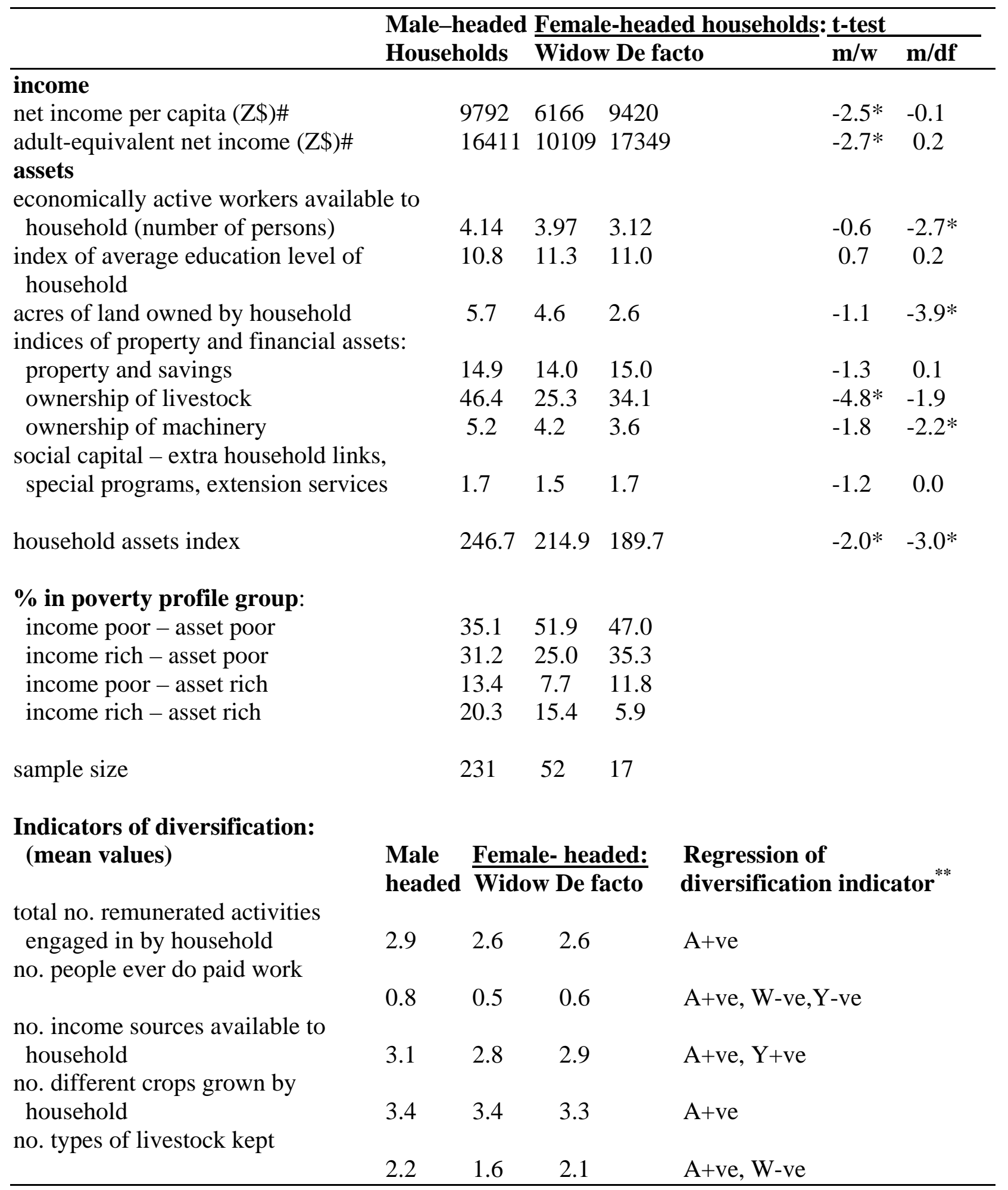

\# gross income including value of self-provisioning less costs of production per person in the household

* t-test for equality of means, equal variance not assumed, significant at $5 \%$ level or higher ** regression of indicator against asset index (A), net income per capita (Y) and dummy variables for de facto (D) and widow headed (W) households. Variables significant at $10 \%$ level or higher indicated. 
Table 3. Land holding by region and gender of head of household (acres)

$\frac{\text { Mutoko }}{\underline{\text { Widow de facto male }}} \frac{\text { Makoni }}{\text { widow de facto male }} \quad \frac{\text { Chivi }}{\text { widow de facto male }}$

\begin{tabular}{|c|c|c|c|c|c|c|c|c|c|}
\hline Mean acreage & 7.5 & 2.2 & 7.7 & 3.0 & 2.8 & 3.4 & 2.2 & 2.1 & 3.6 \\
\hline \multicolumn{10}{|l|}{ Coefficient of } \\
\hline Variation & 113 & 86 & 192 & 80 & 39 & 68 & 68 & 114 & 83 \\
\hline$\%$ no land & 14 & 20 & 15 & 10 & 0 & 8 & 17 & 43 & 17 \\
\hline$\%>5$ acres & 43 & 0 & 21 & 20 & 0 & 17 & 0 & 0 & 21 \\
\hline sample size & 14 & 5 & 81 & 20 & 5 & 75 & 18 & 7 & \\
\hline
\end{tabular}


Table 4. Agricultural productivity, input usage and costs by gender of household head

\begin{tabular}{|c|c|c|c|c|c|c|c|c|c|c|c|}
\hline & \multicolumn{3}{|c|}{ Maize } & \multicolumn{3}{|c|}{ Groundnuts } & \multicolumn{3}{|c|}{ Roundnuts } & \multicolumn{2}{|c|}{ Cotton $^{2}$} \\
\hline & male & widow & $\begin{array}{l}\text { de } \\
\text { facto }\end{array}$ & male & widow & $\begin{array}{l}\text { de } \\
\text { facto }\end{array}$ & male & widow & $\begin{array}{l}\text { de } \\
\text { facto }\end{array}$ & male & widow \\
\hline \% grow & 97 & 96 & 94 & 75 & 71 & 94 & 35 & 33 & 71 & 16 & 19 \\
\hline Acreage $^{1}$ & 2.02 & 1.78 & 1.48 & 0.52 & 0.43 & 0.43 & 0.20 & 0.22 & 0.37 & 0.37 & 0.32 \\
\hline \multicolumn{12}{|c|}{ Yield (where yield per acre $>0$ ): } \\
\hline $\begin{array}{l}\text { Yield } \\
\text { (kg) }\end{array}$ & 869 & 683 & 521 & 483 & 343 & 468 & 206 & 464 & 135 & 693 & 476 \\
\hline \multicolumn{12}{|l|}{ \% use: } \\
\hline Manure & 57 & 42 & 67 & 6 & 4 & 7 & 5 & 0 & 0 & 23 & 11 \\
\hline Fertiliser & 63 & 55 & 67 & 13 & 0 & 14 & 1 & 0 & 0 & 63 & 78 \\
\hline Seed & 100 & 98 & 100 & 97 & 96 & 93 & 92 & 100 & 92 & 100 & 100 \\
\hline \multicolumn{12}{|c|}{ Inputs per acre (kg), where used only: } \\
\hline Manure & 1380 & 1014 & 1094 & & & & & & & 992 & 3000 \\
\hline Fertiliser & 156 & 137 & 175 & 180 & 0 & 150 & & & & 166 & 120 \\
\hline Seed & 14.0 & 13.4 & 17.7 & 31.1 & 31.0 & 45.1 & 23.6 & 34.0 & 18.6 & 11.8 & 15.9 \\
\hline $\begin{array}{l}\text { \% sell } \\
\text { some } \\
\text { crop }\end{array}$ & 45 & 40 & 29 & 24 & 25 & 27 & 14 & 19 & 8 & 100 & 100 \\
\hline \multicolumn{12}{|c|}{ Price achieved per kg output, where sold (Z\$): } \\
\hline Output & 11.4 & 8.3 & 4.2 & 9.8 & 15.3 & 19.2 & & & & 19.1 & 15.5 \\
\hline \multicolumn{12}{|c|}{ Price paid per kg input, where purchased (Z\$): } \\
\hline Fertiliser & 16.8 & 21.3 & 13.7 & & & & & & & 20.5 & 13.6 \\
\hline Seed & 54.9 & 55.2 & 60.8 & & & & & & & 56.4 & 51.0 \\
\hline
\end{tabular}

${ }^{1}$ Calculated for households with land only

${ }^{2}$ Only one de facto female-headed household grew cotton

Input quantities and prices have only been calculated where there are a reasonable number of observations. Only 24 households bought groundnut seeds and only 8 bought roundnut seeds. 
Table 5. Regression analyses of agricultural productivity

Dependent variable: In (yield per acre of each crop)

Heckman selection model, ML (except maize, OLS), with robust standard errors.

\begin{tabular}{|c|c|c|c|c|}
\hline & Maize & Groundnuts & Roundnuts & Cotton $^{1}$ \\
\hline Constant & $\begin{array}{l}4.55 \\
(7.6)^{*}\end{array}$ & $\begin{array}{l}5.65 \\
(42.2)^{*}\end{array}$ & $\begin{array}{l}3.95 \\
(26.4)^{*}\end{array}$ & \begin{tabular}{|l|}
4.52 \\
$(11.6)^{*}$
\end{tabular} \\
\hline $\begin{array}{l}\text { Ln (labour } \\
\text { available) }\end{array}$ & $\begin{array}{l}0.13 \\
(9.1)^{*}\end{array}$ & $\begin{array}{l}0.18 \\
(1.5)\end{array}$ & $\begin{array}{l}0.24 \\
(5.2)^{*}\end{array}$ & \begin{tabular}{|l|}
0.55 \\
$(2.3)^{*}$
\end{tabular} \\
\hline $\begin{array}{l}\text { Ln (paid } \\
\text { labour used) }\end{array}$ & $\begin{array}{l}0.02 \\
(6.3)^{*}\end{array}$ & $\begin{array}{l}0.08 \\
(1.2)\end{array}$ & & $\begin{array}{l}0.04 \\
(1.6)\end{array}$ \\
\hline $\begin{array}{l}\text { Ln (manure } \\
\text { per acre) }\end{array}$ & $\begin{array}{l}0.03 \\
(5.0)^{*}\end{array}$ & $\begin{array}{l}0.05 \\
(1.9)^{*}\end{array}$ & $\begin{array}{l}0.06 \\
(4.7)^{*}\end{array}$ & \begin{tabular}{|l|}
0.03 \\
$(1.3)$ \\
\end{tabular} \\
\hline $\begin{array}{l}\text { Ln (fertiliser } \\
\text { per acre) }\end{array}$ & $\begin{array}{l}0.06 \\
(2.9)^{*}\end{array}$ & $\begin{array}{l}0.05 \\
(7.1)^{*}\end{array}$ & & $\begin{array}{l}0.08 \\
(2.7)^{*} \\
\end{array}$ \\
\hline $\begin{array}{l}\text { Ln (seeds per } \\
\text { acre) }\end{array}$ & $\begin{array}{l}0.37 \\
(2.3)\end{array}$ & $\begin{array}{l}0.11 \\
(3.0)^{*}\end{array}$ & $\begin{array}{l}0.13 \\
(1.6)\end{array}$ & $\begin{array}{l}0.56 \\
(2.2)^{*}\end{array}$ \\
\hline $\begin{array}{l}\text { Ln (acres of } \\
\text { crop) }\end{array}$ & $\begin{array}{l}-0.26 \\
(-2.4)\end{array}$ & $\begin{array}{l}-0.45 \\
(-15.6) *\end{array}$ & $\begin{array}{l}-0.71 \\
(-3.2)^{*}\end{array}$ & \begin{tabular}{|l|}
-0.25 \\
$(-2.8)^{*}$ \\
\end{tabular} \\
\hline $\begin{array}{l}\text { Ln (no. cattle } \\
\text { owned) }\end{array}$ & $\begin{array}{l}0.03 \\
(2.5)\end{array}$ & & & $\begin{array}{l}0.05 \\
(8.7)^{*} \\
\end{array}$ \\
\hline $\begin{array}{l}\text { Ln (farm } \\
\text { machinery) }\end{array}$ & $\begin{array}{l}0.12 \\
(6.3)^{*}\end{array}$ & & & \\
\hline Makoni & $\begin{array}{l}0.33 \\
(3.1)^{*}\end{array}$ & $\begin{array}{l}0.11 \\
(3.6)^{*}\end{array}$ & & \\
\hline Mutoko & $\begin{array}{l}0.75 \\
(3.9)^{*}\end{array}$ & $\begin{array}{l}0.40 \\
(39.3)^{*}\end{array}$ & & \begin{tabular}{|l|}
-0.28 \\
$(-4.9)^{*}$
\end{tabular} \\
\hline $\begin{array}{l}\text { Female-headed } \\
\text { household }\end{array}$ & $\begin{array}{l}0.08 \\
(0.8)\end{array}$ & $\begin{array}{l}-0.17 \\
(-0.9)\end{array}$ & $\begin{array}{l}0.08 \\
(0.4)\end{array}$ & \begin{tabular}{|l|}
-0.63 \\
$(-6.2)^{*}$
\end{tabular} \\
\hline $\begin{array}{l}\text { Ln (education } \\
\text { of household) }\end{array}$ & $\begin{array}{l}0.00 \\
(0.0)\end{array}$ & & & \\
\hline $\begin{array}{l}\text { Extension } \\
\text { service }\end{array}$ & $\begin{array}{l}0.03 \\
(0.3)\end{array}$ & & & \\
\hline $\begin{array}{l}\text { Ln (non-crop } \\
\text { income p.c.) }\end{array}$ & $\begin{array}{l}0.01 \\
(1.0)\end{array}$ & $\begin{array}{l}-0.02 \\
(-3.7)^{*}\end{array}$ & $\begin{array}{l}0.01 \\
(3.5)^{*}\end{array}$ & $\begin{array}{l}-0.01 \\
(-0.7) \\
\end{array}$ \\
\hline Sample size & 283 & 184 & 91 & 45 \\
\hline $\mathrm{R}^{2}$ & 0.43 & & & \\
\hline $\begin{array}{l}\text { Log pseudo } \\
\text { likelihood }\end{array}$ & & -233.8 & -122.5 & \begin{tabular}{|l|}
-37.4 \\
\end{tabular} \\
\hline Lambda (mills) & & $\begin{array}{l}0.59 \\
(18.6)^{*}\end{array}$ & $\begin{array}{l}0.89 \\
(8.7)^{*}\end{array}$ & $\begin{array}{l}0.52 \\
(4.9)^{*}\end{array}$ \\
\hline
\end{tabular}

Robust $\mathrm{t}$ and $\mathrm{z}$ statistics in parentheses, * indicates $10 \%$ level of significance or higher

Selectivity corrected equation reported. Probit regression on whether grow crop included all variables included in the yields regression, the education level of the household, the total acreage of land owned, the number of people in the household and whether the house was legally registered in the name of someone in the household. Female-headship did not affect crop choice.

${ }^{1}$ Excludes Makoni where no cotton is grown 
Table 6. Regression analysis of input usage (labour time/ kg per acre)

\begin{tabular}{|c|c|c|c|c|c|c|c|c|}
\hline & \multicolumn{4}{|l|}{ MAIZE } & \multicolumn{4}{|c|}{ ALL CROPS } \\
\hline & $\begin{array}{l}\text { House- } \\
\text { hold } \\
\text { labour }{ }^{1} \\
\text { (OLS) }\end{array}$ & $\begin{array}{l}\text { Manure }^{1} \\
\text { (tobit) }\end{array}$ & $\begin{array}{l}\text { Fertiliser }^{1} \\
\text { (tobit) }\end{array}$ & $\begin{array}{l}\text { Seeds }^{1} \\
\text { (OLS) }\end{array}$ & $\begin{array}{l}\text { House- } \\
\text { hold } \\
\text { labour }^{1} \\
\text { (OLS) }\end{array}$ & $\begin{array}{l}\text { Manure }^{1} \\
\text { (tobit) }\end{array}$ & $\begin{array}{l}\text { Fertiliser }^{1} \\
\text { (tobit) }\end{array}$ & $\begin{array}{l}\text { Seeds }^{1} \\
(\mathrm{OLS})\end{array}$ \\
\hline Constant & $\begin{array}{l}6.41 \\
(9.10)^{*}\end{array}$ & $\begin{array}{l}-14.22 \\
(-1.76)^{*}\end{array}$ & $\begin{array}{l}-4.16 \\
(-0.85)\end{array}$ & $\begin{array}{l}1.94 \\
(6.65)^{*}\end{array}$ & \begin{tabular}{|l|}
6.31 \\
$(9.05) *$
\end{tabular} & $\begin{array}{l}2.22 \\
(0.45)\end{array}$ & $\begin{array}{l}-1.29 \\
(-0.45)\end{array}$ & $\begin{array}{l}2.13 \\
(11.09)^{*}\end{array}$ \\
\hline $\begin{array}{l}\text { No. in } \\
\text { household }{ }^{1}\end{array}$ & $\begin{array}{l}0.45 \\
(5.06) *\end{array}$ & $\begin{array}{l}0.77 \\
(0.57)\end{array}$ & $\begin{array}{l}-0.48 \\
(-0.58)\end{array}$ & $\begin{array}{l}0.10 \\
(0.26)\end{array}$ & $\begin{array}{l}0.44 \\
(4.10)^{*}\end{array}$ & $\begin{array}{l}-0.40 \\
(-0.48)\end{array}$ & $\begin{array}{l}-0.48 \\
(-1.00)\end{array}$ & $\begin{array}{l}0.19 \\
(0.91)\end{array}$ \\
\hline $\begin{array}{l}\text { Education } \\
\text { household }^{1}\end{array}$ & $\begin{array}{l}0.13 \\
(2.17)\end{array}$ & $\begin{array}{l}1.86 \\
(1.61)\end{array}$ & $\begin{array}{l}-0.21 \\
(-0.44)\end{array}$ & $\begin{array}{l}0.05 \\
(0.43)\end{array}$ & $\begin{array}{l}0.12 \\
(1.83)\end{array}$ & $\begin{array}{l}0.40 \\
(0.75)\end{array}$ & $\begin{array}{l}-0.25 \\
(-0.86)\end{array}$ & $\begin{array}{l}0.11 \\
(1.16)\end{array}$ \\
\hline $\begin{array}{l}\text { Number of } \\
\text { cattle }^{1}\end{array}$ & $\begin{array}{l}-0.00 \\
(-0.20)\end{array}$ & $\begin{array}{l}1.84 \\
(3.47)^{*}\end{array}$ & \begin{tabular}{|l|}
-0.30 \\
$(-0.96)$
\end{tabular} & $\begin{array}{l}0.01 \\
(1.50)\end{array}$ & $\begin{array}{l}-0.01 \\
(-0.68)\end{array}$ & $\begin{array}{l}0.98 \\
(3.09)^{*}\end{array}$ & $\begin{array}{l}-0.22 \\
(-1.21)\end{array}$ & $\begin{array}{l}-0.05 \\
(-1.24)\end{array}$ \\
\hline $\begin{array}{l}\text { Maize/land } \\
\text { acreage }^{1}\end{array}$ & $\begin{array}{l}-0.96 \\
(- \\
24.40) *\end{array}$ & $\begin{array}{l}2.17 \\
(3.86)^{*}\end{array}$ & $\begin{array}{l}1.59 \\
(4.28)^{*}\end{array}$ & $\begin{array}{l}0.91 \\
(24.42) *\end{array}$ & $\begin{array}{l}-0.96 \\
(- \\
26.68) *\end{array}$ & $\begin{array}{l}-0.32 \\
(-0.72)\end{array}$ & $\begin{array}{l}-0.75 \\
(-2.98) *\end{array}$ & $\begin{array}{l}-0.76 \\
(-7.85) *\end{array}$ \\
\hline $\begin{array}{l}\text { Age head } \\
\text { household }^{1}\end{array}$ & $\begin{array}{l}0.28 \\
(1.83)\end{array}$ & $\begin{array}{l}1.19 \\
(0.59)\end{array}$ & $\begin{array}{l}-1.66 \\
(-1.33)\end{array}$ & $\begin{array}{l}0.03 \\
(0.39)\end{array}$ & $\begin{array}{l}0.31 \\
(1.77)\end{array}$ & $\begin{array}{l}-1.25 \\
(-1.00)\end{array}$ & $\begin{array}{l}-0.75 \\
(-1.02)\end{array}$ & $\begin{array}{l}0.02 \\
(0.12)\end{array}$ \\
\hline $\begin{array}{l}\text { Livestock } \\
\text { ownership }^{1}\end{array}$ & $\begin{array}{l}-0.02 \\
(-0.64)\end{array}$ & $\begin{array}{l}0.22 \\
(0.32)\end{array}$ & $\begin{array}{l}0.31 \\
(0.80)\end{array}$ & $\begin{array}{l}-0.04 \\
(-2.03)\end{array}$ & $\begin{array}{l}-0.03 \\
(-0.62)\end{array}$ & $\begin{array}{l}0.49 \\
(1.18)\end{array}$ & $\begin{array}{l}0.60 \\
(2.56)^{*}\end{array}$ & $\begin{array}{l}0.14 \\
(6.37) *\end{array}$ \\
\hline $\begin{array}{l}\text { Farm } \\
\text { machinery }{ }^{1}\end{array}$ & $\begin{array}{l}0.03 \\
(2.92)\end{array}$ & $\begin{array}{l}0.52 \\
(0.81)\end{array}$ & $\begin{array}{l}1.06 \\
(2.63)^{*}\end{array}$ & $\begin{array}{l}-0.17 \\
(-2.03)\end{array}$ & $\begin{array}{l}0.02 \\
(1.38)\end{array}$ & $\begin{array}{l}0.55 \\
(1.32)\end{array}$ & $\begin{array}{l}0.73 \\
(3.06)^{*}\end{array}$ & $\begin{array}{l}0.04 \\
(1.11)\end{array}$ \\
\hline $\begin{array}{l}\text { Non-farm } \\
\text { income } \mathrm{pc}^{1}\end{array}$ & $\begin{array}{l}0.01 \\
(1.11)\end{array}$ & $\begin{array}{l}-0.19 \\
(-1.76)^{*}\end{array}$ & \begin{tabular}{|l|}
0.00 \\
$(0.04)$
\end{tabular} & $\begin{array}{l}1-0.01 \\
(-0.92)\end{array}$ & $\begin{array}{l}0.01 \\
(1.30)\end{array}$ & $\begin{array}{l}0.05 \\
(0.74)\end{array}$ & $\begin{array}{l}0.02 \\
(0.42)\end{array}$ & $\begin{array}{l}0.00 \\
(0.03)\end{array}$ \\
\hline Land good & $\begin{array}{l}0.10 \\
(2.04)\end{array}$ & $\begin{array}{l}-2.26 \\
(-1.79) *\end{array}$ & $\begin{array}{l}-0.20 \\
(-0.26)\end{array}$ & $\begin{array}{l}-0.12 \\
(-0.83)\end{array}$ & \begin{tabular}{|l|}
0.08 \\
$(4.17) *$
\end{tabular} & $\begin{array}{l}-0.22 \\
(-0.28)\end{array}$ & $\begin{array}{l}-0.23 \\
(-0.50)\end{array}$ & $\begin{array}{l}-0.04 \\
(-0.52)\end{array}$ \\
\hline Land poor & $\begin{array}{l}-0.00 \\
(-0.00)\end{array}$ & $\begin{array}{l}-0.91 \\
(-0.65)\end{array}$ & $\begin{array}{l}0.12 \\
(0.14)\end{array}$ & $\begin{array}{l}0.11 \\
(2.25)\end{array}$ & $\begin{array}{l}0.03 \\
(0.30)\end{array}$ & $\begin{array}{l}0.07 \\
(0.08)\end{array}$ & $\begin{array}{l}-0.08 \\
(-0.17)\end{array}$ & $\begin{array}{l}0.04 \\
(3.45) *\end{array}$ \\
\hline Land wet & $\begin{array}{l}-0.05 \\
(-0.88)\end{array}$ & $\begin{array}{l}2.99 \\
(1.76)^{*}\end{array}$ & $\begin{array}{l}0.52 \\
(0.49)\end{array}$ & $\begin{array}{l}0.24 \\
(2.08)\end{array}$ & $\begin{array}{l}-0.04 \\
(-0.45)\end{array}$ & $\begin{array}{l}0.61 \\
(0.59)\end{array}$ & $\begin{array}{l}0.38 \\
(0.63)\end{array}$ & $\begin{array}{l}-0.19 \\
(-0.98)\end{array}$ \\
\hline Land dry & $\begin{array}{l}-0.14 \\
(- \\
4.54)^{*}\end{array}$ & $\begin{array}{l}2.91 \\
(2.03) *\end{array}$ & $\begin{array}{l}-0.05 \\
(-0.06)\end{array}$ & $\begin{array}{l}0.13 \\
(0.56)\end{array}$ & $\begin{array}{l}-0.15 \\
(- \\
5.92)^{*} \\
\end{array}$ & $\begin{array}{l}0.79 \\
(0.90)\end{array}$ & $\begin{array}{l}-0.08 \\
(-0.15)\end{array}$ & $\begin{array}{l}-0.27 \\
(-0.99)\end{array}$ \\
\hline Mutoko & $\begin{array}{l}-0.20 \\
(- \\
6.35)^{*}\end{array}$ & $\begin{array}{l}-3.11 \\
(-2.27)^{*}\end{array}$ & \begin{tabular}{|l}
12.23 \\
$(12.54)^{*}$
\end{tabular} & $\begin{array}{l}-0.15 \\
(-2.45)\end{array}$ & $\begin{array}{l}-0.23 \\
(- \\
6.40) *\end{array}$ & $\begin{array}{l}-0.72 \\
(-0.82)\end{array}$ & $\begin{array}{l}7.01 \\
(12.66)^{*}\end{array}$ & $\begin{array}{l}-0.01 \\
(-0.43)\end{array}$ \\
\hline Makoni & $\begin{array}{l}-0.11 \\
(- \\
6.11)^{*}\end{array}$ & $\begin{array}{l}2.82 \\
(2.18) *\end{array}$ & $\begin{array}{l}9.90 \\
(10.48)^{*}\end{array}$ & $\begin{array}{l}-0.16 \\
(-5.40) *\end{array}$ & $\begin{array}{l}-0.09 \\
(- \\
4.27)^{*}\end{array}$ & $\begin{array}{l}1.66 \\
(1.94)^{*}\end{array}$ & $\begin{array}{l}5.99 \\
(10.98)^{*}\end{array}$ & $\begin{array}{l}0.24 \\
(3.94)^{*}\end{array}$ \\
\hline $\begin{array}{l}\text { Extension } \\
\text { service }\end{array}$ & $\begin{array}{l}-0.05 \\
(-1.19)\end{array}$ & $\begin{array}{l}-0.34 \\
(-0.30)\end{array}$ & $\begin{array}{l}0.13 \\
(0.18)\end{array}$ & $\begin{array}{l}-0.11 \\
(-0.64)\end{array}$ & $\begin{array}{l}-0.06 \\
(-1.13)\end{array}$ & $\begin{array}{l}1.34 \\
(1.85)^{*}\end{array}$ & $\begin{array}{l}0.37 \\
(0.90)\end{array}$ & $\begin{array}{l}0.09 \\
(1.10)\end{array}$ \\
\hline Widow & $\begin{array}{l}-0.067 \\
(-0.57)\end{array}$ & $\begin{array}{l}-2.01 \\
(-1.29)\end{array}$ & $\begin{array}{l}-0.03 \\
(-0.03)\end{array}$ & $\begin{array}{l}-0.04 \\
(-0.08)\end{array}$ & $\begin{array}{l}-0.11 \\
(-0.76)\end{array}$ & $\begin{array}{l}-0.22 \\
(-0.20)\end{array}$ & $\begin{array}{l}-0.40 \\
(-0.65)\end{array}$ & $\begin{array}{l}0.16 \\
(1.26)\end{array}$ \\
\hline De facto & $\begin{array}{l}-0.37 \\
(- \\
3.05)^{*}\end{array}$ & $\begin{array}{l}2.59 \\
(1.12)\end{array}$ & $\begin{array}{l}1.90 \\
(1.30)\end{array}$ & $\begin{array}{l}0.37 \\
(0.66)\end{array}$ & $\begin{array}{l}-0.38 \\
(- \\
2.94)^{*}\end{array}$ & $\begin{array}{l}-0.69 \\
(-0.44)\end{array}$ & $\begin{array}{l}-0.29 \\
(-0.32)\end{array}$ & $\begin{array}{l}-0.14 \\
(-0.61)\end{array}$ \\
\hline
\end{tabular}




\begin{tabular}{|c|c|c|c|c|c|c|c|c|}
\hline $\begin{array}{l}\text { Grow } \\
\text { roundnuts }\end{array}$ & & & & & $\begin{array}{l}-0.02 \\
(-0.79)\end{array}$ & $\begin{array}{l}-0.62 \\
(-0.80)\end{array}$ & $\begin{array}{l}-0.52 \\
(-1.14)\end{array}$ & $\begin{array}{l}0.06 \\
(0.64)\end{array}$ \\
\hline $\begin{array}{l}\text { Grow } \\
\text { groundnuts }\end{array}$ & & & & & $\begin{array}{l}0.02 \\
(0.45)\end{array}$ & $\begin{array}{l}0.91 \\
(1.17)\end{array}$ & $\begin{array}{l}0.24 \\
(0.52)\end{array}$ & $\begin{array}{l}0.48 \\
(30.27)^{*}\end{array}$ \\
\hline $\begin{array}{l}\text { Grow } \\
\text { cotton }\end{array}$ & & & & & $\begin{array}{l}0.12 \\
(0.67)\end{array}$ & $\begin{array}{l}-0.47 \\
(-0.40)\end{array}$ & $\begin{array}{l}1.00 \\
(1.43)\end{array}$ & $\begin{array}{l}0.19 \\
(0.50)\end{array}$ \\
\hline $\begin{array}{l}\text { Female } \\
\text { head * } \\
\text { grow } \\
\text { cotton }\end{array}$ & & & & & $\begin{array}{l}0.13 \\
(0.77)\end{array}$ & $\begin{array}{l}-3.88 \\
(-1.69) *\end{array}$ & $\begin{array}{l}1.63 \\
(1.29)\end{array}$ & $\begin{array}{l}-0.06 \\
(-0.39)\end{array}$ \\
\hline $\begin{array}{l}\text { R2/ LR } \\
\text { chi2 }\end{array}$ & 0.70 & $113.3^{*}$ & $214.3^{*}$ & 0.46 & 0.82 & $75.5^{*}$ & $200.2 *$ & 0.39 \\
\hline
\end{tabular}

${ }^{1}$ logarithmic values

* indicates significance at $10 \%$ level or more

OLS regressions use robust standard errors 
Table 7. Regression analysis of prices paid and received (Z\$ per kg)

\begin{tabular}{|c|c|c|c|c|c|c|c|}
\hline & $\begin{array}{l}\text { Maize } \\
\text { Output } \\
\text { sales }^{1}\end{array}$ & $\begin{array}{l}\text { Maize } \\
\text { Input } \\
\text { of } \\
\text { seed }^{1}\end{array}$ & $\begin{array}{l}\text { Maize } \\
\text { Input of } \\
\text { fertiliser }^{1}\end{array}$ & $\begin{array}{l}\text { Groundnuts } \\
\text { Output } \\
\text { sales }^{1}\end{array}$ & $\begin{array}{l}\text { Cotton } \\
\text { Output } \\
\text { sales }\end{array}$ & $\begin{array}{l}\text { Cotton } \\
\text { Input } \\
\text { of seed }\end{array}$ & $\begin{array}{l}\text { Cotton } \\
\text { Input of } \\
\text { fertiliser }^{1}\end{array}$ \\
\hline No. grow & 298 & 298 & 298 & 205 & 45 & 45 & 45 \\
\hline $\begin{array}{l}\text { No. sell / } \\
\text { purchase }\end{array}$ & 131 & 226 & 166 & 50 & 45 & 36 & 32 \\
\hline Method & Tobit & Tobit & Tobit & Tobit & $\begin{array}{l}\text { OLS } \\
\text { robust } \\
\text { s.e. }\end{array}$ & Tobit & Tobit \\
\hline \multicolumn{8}{|l|}{ Variables: } \\
\hline Makoni & $\begin{array}{l}0.36 \\
(2.33)^{*}\end{array}$ & $\begin{array}{l}2.20 \\
(3.11)^{*}\end{array}$ & $\begin{array}{l}2.84 \\
(7.94)^{*}\end{array}$ & $\begin{array}{l}0.34 \\
(0.50)\end{array}$ & & & \\
\hline Mutoko & $\begin{array}{l}0.76 \\
(4.81)^{*}\end{array}$ & $\begin{array}{l}1.69 \\
(2.33) *\end{array}$ & $\begin{array}{l}3.11 \\
(8.56)^{*}\end{array}$ & $\begin{array}{l}1.09 \\
(1.60)\end{array}$ & $\begin{array}{l}6.04 \\
(1.24)\end{array}$ & $\begin{array}{l}101.44 \\
(3.61)^{*}\end{array}$ & $\begin{array}{l}1.46 \\
(1.99)^{*}\end{array}$ \\
\hline Land good & $\begin{array}{l}0.17 \\
(1.13) \\
\end{array}$ & $\begin{array}{l}0.27 \\
(0.41)\end{array}$ & $\begin{array}{l}-0.01 \\
(-0.02)\end{array}$ & $\begin{array}{l}-0.86 \\
(-1.37)\end{array}$ & $\begin{array}{l}-1.44 \\
(-0.56)\end{array}$ & $\begin{array}{l}-21.40 \\
(-0.90)\end{array}$ & $\begin{array}{l}-0.06 \\
(-0.10)\end{array}$ \\
\hline Land poor & $\begin{array}{l}0.11 \\
(0.65)\end{array}$ & $\begin{array}{l}0.41 \\
(0.55)\end{array}$ & $\begin{array}{l}-0.06 \\
(-0.17)\end{array}$ & $\begin{array}{l}-0.04 \\
(-0.05)\end{array}$ & $\begin{array}{l}17.07 \\
(0.80)\end{array}$ & $\begin{array}{l}-18.24 \\
(-0.37)\end{array}$ & $\begin{array}{l}-0.86 \\
(-0.69) \\
\end{array}$ \\
\hline Land wet & $\begin{array}{l}0.09 \\
(0.44) \\
\end{array}$ & $\begin{array}{l}0.81 \\
(0.89) \\
\end{array}$ & $\begin{array}{l}0.18 \\
(0.45) \\
\end{array}$ & $\begin{array}{l}3.34 \\
(3.72) *\end{array}$ & $\begin{array}{l}13.92 \\
(2.68)\end{array}$ & $\begin{array}{l}21.12 \\
(0.51)\end{array}$ & $\begin{array}{l}0.38 \\
(0.34)\end{array}$ \\
\hline Land dry & $\begin{array}{l}0.11 \\
(0.67)\end{array}$ & $\begin{array}{l}0.17 \\
(0.24)\end{array}$ & $\begin{array}{l}0.03 \\
(0.09) \\
\end{array}$ & $\begin{array}{l}1.03 \\
(1.35) \\
\end{array}$ & $\begin{array}{l}1.10 \\
(0.32) \\
\end{array}$ & $\begin{array}{l}-18.49 \\
(-0.65) \\
\end{array}$ & \begin{tabular}{|l|}
0.39 \\
$(0.50)$ \\
\end{tabular} \\
\hline $\begin{array}{l}\text { Education } \\
\text { household }^{1}\end{array}$ & $\begin{array}{l}-0.05 \\
(-0.54)\end{array}$ & $\begin{array}{l}-0.28 \\
(-0.63)\end{array}$ & $\begin{array}{l}0.08 \\
(0.44)\end{array}$ & $\begin{array}{l}0.60 \\
(0.90)\end{array}$ & $\begin{array}{l}0.59 \\
(7.70)^{*}\end{array}$ & $\begin{array}{l}21.51 \\
(0.54)\end{array}$ & $\begin{array}{l}-1.77 \\
(-1.93) *\end{array}$ \\
\hline $\begin{array}{l}\text { Non-farm } \\
\text { income } \\
\mathrm{pc}^{1}\end{array}$ & $\begin{array}{l}0.01 \\
(0.53)\end{array}$ & $\begin{array}{l}0.10 \\
(1.65) *\end{array}$ & $\begin{array}{l}0.04 \\
(1.22)\end{array}$ & $\begin{array}{l}0.02 \\
(0.35)\end{array}$ & $\begin{array}{l}-0.37 \\
(0.63)\end{array}$ & $\begin{array}{l}3.52 \\
(1.54)\end{array}$ & $\begin{array}{l}0.00 \\
(0.05)\end{array}$ \\
\hline $\begin{array}{l}\text { Extension } \\
\text { service }\end{array}$ & $\begin{array}{l}0.27 \\
(1.74)^{*}\end{array}$ & $\begin{array}{l}0.88 \\
(1.23)\end{array}$ & $\begin{array}{l}0.04 \\
(0.13)\end{array}$ & $\begin{array}{l}0.02 \\
(0.03)\end{array}$ & $\begin{array}{l}-3.66 \\
(-0.72)\end{array}$ & $\begin{array}{l}54.74 \\
(1.76)^{*}\end{array}$ & $\begin{array}{l}0.08 \\
(0.10)\end{array}$ \\
\hline $\begin{array}{l}\text { Social } \\
\text { capital }\end{array}$ & $\begin{array}{l}-0.03 \\
(-0.39)\end{array}$ & $\begin{array}{l}0.03 \\
(0.10)\end{array}$ & $\begin{array}{l}0.07 \\
(0.50)\end{array}$ & $\begin{array}{l}0.14 \\
(0.54)\end{array}$ & $\begin{array}{l}5.87 \\
(2.14)\end{array}$ & $\begin{array}{l}-13.88 \\
(-1.08)\end{array}$ & $\begin{array}{l}-0.39 \\
(-1.17) \\
\end{array}$ \\
\hline $\begin{array}{l}\text { Land } \\
\text { owned }^{1}\end{array}$ & $\begin{array}{l}0.16 \\
(2.08)^{*}\end{array}$ & $\begin{array}{l}-0.06 \\
(-0.16)\end{array}$ & $\begin{array}{l}0.12 \\
(0.75)\end{array}$ & $\begin{array}{l}1.12 \\
(2.74) *\end{array}$ & $\begin{array}{l}-0.72 \\
(-0.57)\end{array}$ & $\begin{array}{l}-37.65 \\
(- \\
3.58)^{*}\end{array}$ & $\begin{array}{l}0.20 \\
(0.68)\end{array}$ \\
\hline Widow & $\begin{array}{l}-0.11 \\
(-0.64)\end{array}$ & $\begin{array}{l}-0.62 \\
(-0.79)\end{array}$ & $\begin{array}{l}-0.29 \\
(-0.81)\end{array}$ & $\begin{array}{l}0.11 \\
(0.14)\end{array}$ & $\begin{array}{l}-3.41 \\
(- \\
13.92)^{*}\end{array}$ & $\begin{array}{l}-40.38 \\
(-1.37)\end{array}$ & $\begin{array}{l}0.62 \\
(0.82)\end{array}$ \\
\hline De facto & $\begin{array}{l}-0.53 \\
(- \\
1.85) *\end{array}$ & $\begin{array}{l}0.34 \\
(0.26)\end{array}$ & $\begin{array}{l}0.30 \\
(0.52)\end{array}$ & $\begin{array}{l}1.05 \\
(1.00)\end{array}$ & & & \\
\hline Constant & $\begin{array}{l}0.23 \\
(0.75)\end{array}$ & $\begin{array}{l}-0.60 \\
(-0.43)\end{array}$ & $\begin{array}{l}-2.01 \\
(-3.09) *\end{array}$ & $\begin{array}{l}-6.85 \\
(-3.40) *\end{array}$ & & $\begin{array}{l}10.77 \\
(0.10)\end{array}$ & $\begin{array}{l}4.75 \\
(2.00)^{*}\end{array}$ \\
\hline R 2 & & & & & 0.30 & & \\
\hline LR chi 2 & $47.2^{*}$ & 18.6 & 108.6* & $31.9 *$ & & $18.9 *$ & 16.4 \\
\hline
\end{tabular}


${ }^{1}$ logarithmic values

* significant at $10 \%$ level or more 
Figure 1. Income per capita, cumulative

\section{percentage}

poverty line $=\mathbf{Z} \$ 8315$

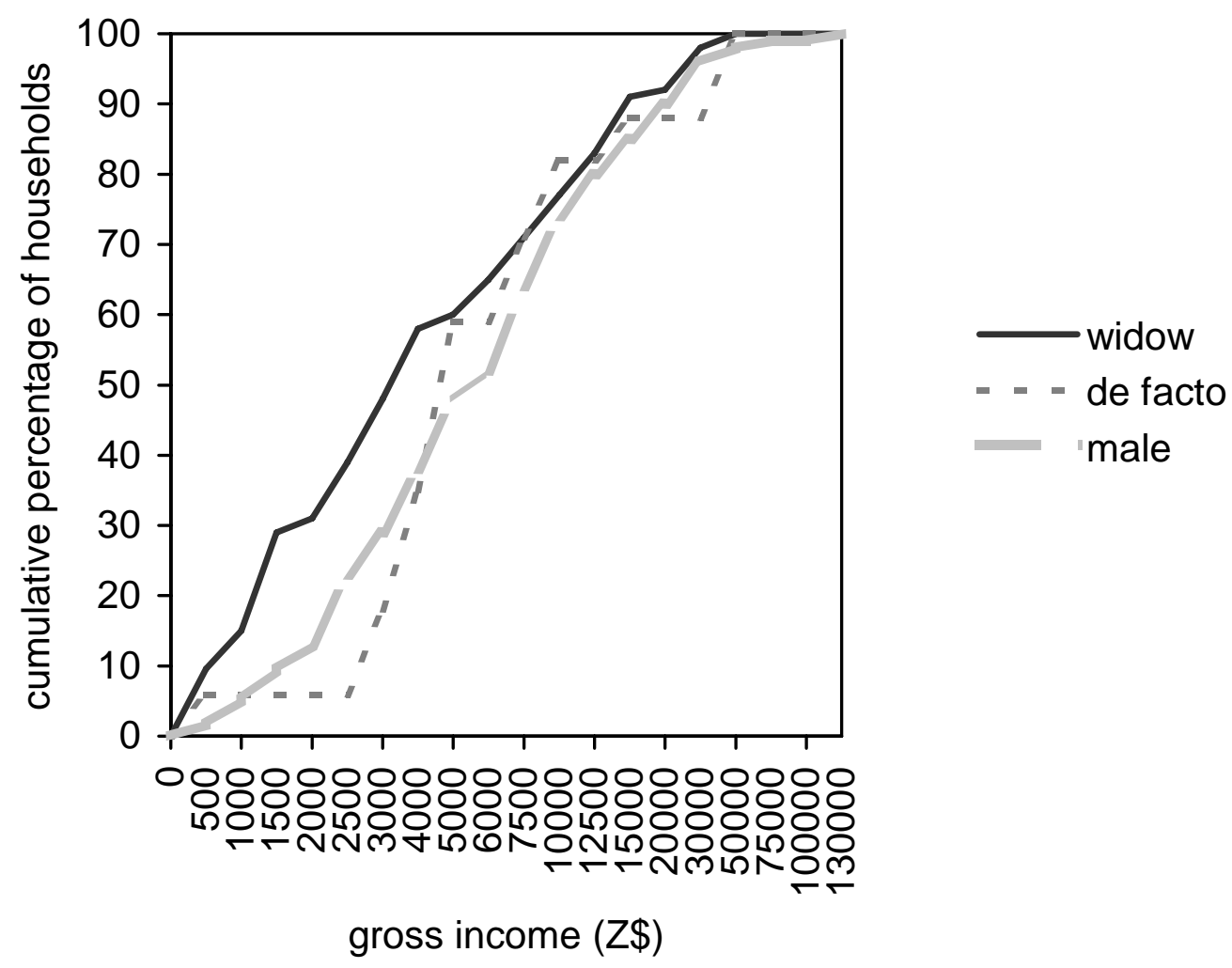




\section{References}

AGRITEX (2002) 'Gender issues, constraints and potentials in AGRITEX - an overview'. www.fao.org report

Bardhan, P. and Udry, C.(1999), Development Economics, Oxford University Press.

Blackden, C. Mark and Chitra Bhanu (1999) Gender, Growth and Poverty reduction. Special Program of Assistance for Africa. 1998 status report on poverty in Sub-Saharan Africa, World Bank: Washington

Boserup, Esther (1970) Women's Role in Economic Development, New York: St. Martin's Press

Bourdillon, Michael (1976) The Shona Peoples, Harare: Mambo Press

Bryceson, D. F. (1999) `African rural labour, income diversification and livelihood approaches: a long-term development perspective', Review of African Political Economy (80) pp.171-189

Carney, D. (ed) (1998) ‘Sustainable Rural Livelihoods. What contributions can we make?’ London: Department for International Development

Chant, Sylvia (1997) Women-Headed Households: Diversity and Dynamics in the Developing World, Macmillan

Chant, Sylvia (2003) 'New Contributions to the Analysis of Poverty: Methodological and Conceptual Challenges to Understanding Poverty from a Gender Perspective', CEPAL, U.N. Women's Development Unit, Santiago:Chile

Chipika, Stephen, Chisvo, Munhamo and Chipika, Jesimen T. (1998) Economic Reform and Smallholder Communal Development in Zimbabwe, Sapes Books, Harare

Coldham, Simon (2000) 'Land inheritance issues in Zimbabwe today', in Tanya A. S. BowyerBower and Colin Stoneman (eds) Land Reform in Zimbabwe: constraints and prospects, Aldershot: Ashgate, pp.

Davison, Jean (1997) Gender, Lineage and Ethnicity in Southern Africa, Oxford: Westview Press

Deaton, Angus and Salman Zaidi (2002) 'Guidelines for constructing consumption aggregates for welfare analysis’, Living Standards Measurement Study WP 135, May, World Bank: Washington

Dreze, J. and Sen, A. (1995) India. Economic Development and Social Opportunity, Oxford: Clarendon Press

Ellis, Frank (1998) `Household strategies and rural livelihood diversification’, Journal of Development Studies (35) pp.1-38

Ellis, Frank and H. Ade Freeman (2004) `Rural livelihoods and poverty reduction strategies in four African countries’, Journal of Development Studies (40) pp.1-30 
Gwaunza, Elizabeth (1998) `The impact of labour migration on family organisation in Zimbabwe', in Sachikonye, Lloyd (ed.) Labour Markets and Migration Policy in Southern Africa, Harare: Sapes Books, pp.49-55

Hellum, Anne and Bill Derman (2004) 'Land reform and human rights in contemporary Zimbabwe: balancing individual and social justice through an integrated human rights framework', World Development (32) pp.1785-1805

Horrell, Sara, Hazel Johnson and Paul Mosley with Supriya Garikipati, June Rock and Arjan Verschoor (2006) Work, Female Empowerment and Escape from Poverty (draft manuscript).

Ikdahl, Ingunn, Anne Hellum, Randi Kaarhus, Tor A Benjaminsen, Patricia Kamori-Mbote (2005) 'Human Rights Formalisation and Women's Land Rights in Southern and Eastern Africa', Studies in Women's Law no. 57, University of Oslo: Institute of Women's Law

Jacobs, Susie (2000) 'The effects of land reform on gender relations in Zimbabwe', in Tanya A. S. Bowyer-Bower and Colin Stoneman (eds) Land Reform in Zimbabwe: constraints and prospects, Aldershot: Ashgate, pp.175-186.

Kennedy, Eileen and Lawrence Haddad (1994) `Are pre-schoolers from female-headed households less malnourished? : A comparative analysis of results from Ghana and Kenya', Journal of Development Studies, April, pp.680-695

Mate, Rekopantswe (2001) 'Land, women and sugar in Chipiwa', in Paul Hebinck and Michael Bourdillon (eds) Women, Men and Work: rural livelihoods in south-eastern Zimbabwe, Harare: Weaver Press, pp.37-60

Pankhurst, Donna and Susie Jacobs (1988) `Land tenure, gender relations and agricultural production: the case of Zimbabwe's peasantry', in Jean Davison (ed) Agriculture, Women and Land: the African experience, London: Westview, pp.202-227

Quisumbing, Agnes (1996) `Male-female differences in agricultural productivity: methodological issues and empirical evidence', World Development (24) pp.1579-1595

Quisumbing, Agnes, Lawrence Haddad and Christine Pena (2001) `Are women over-represented among the poor? An analysis of poverty in 10 developing countries', Journal of Development Economics (66) pp.225-269

Sen, Amartya (1981) Poverty and Famines, Oxford: Clarendon Press

Sen, Amartya (1999) Development as Freedom, Oxford: Oxford University Press

Udry, Christopher (1996) 'Gender, agricultural production, and the theory of the household', Journal of Political Economy (104) pp.1010-1046

Vijfhuizen, Carin (2002) The People You Live With, Harare: Weaver Press

World Bank (2000) ‘World Development Report 2000/01: Attacking Poverty’. New York, Oxford University Press for World Bank 
Zimbabwe Human Development Report (2003) 'Redirecting our responses to HIV and AIDS', University of Zimbabwe: Poverty Reduction Forum, Institute of Development Studies

Zimbabwe National Vulnerability Assessment Committee (ZNVAC) (2002) 'Zimbabwe Emergency Food Security and Vulnerability Assessment Report’, 20 December, Harare 